\title{
Bacteriophages in Biological Wastewater Treatment Systems: Occurrence, Characterization, and Function
}

\author{
Viviane Runa ${ }^{1,2}$, Jannis Wenk ${ }^{2,3}$, Simon Bengtsson ${ }^{4}$, Brian V. Jones ${ }^{5}$ and \\ Ana B. Lanham ${ }^{1,2,3 *}$ \\ ${ }^{1}$ Centre for Sustainable and Circular Technologies, University of Bath, Bath, United Kingdom, ${ }^{2}$ Department of Chemical \\ Engineering, University of Bath, Bath, United Kingdom, ${ }^{3}$ Water Innovation and Research Centre, University of Bath, Bath, \\ United Kingdom, ${ }^{4}$ Promiko AB, Lomma, Sweden, ${ }^{5}$ Department of Biology and Biochemistry, University of Bath, Bath, \\ United Kingdom
}

OPEN ACCESS

Edited by:

Hany Anany,

Agriculture and Agri-Food Canada (AAFC), Canada

Reviewed by:

Sanna Sillankorva,

International Iberian Nanotechnology

Laboratory (INL), Portugal

Paul Hyman,

Ashland University, United States

*Correspondence:

Ana B. Lanham

A.Lanham@bath.ac.uk

Specialty section:

This article was submitted to

Phage Biology,

a section of the journal

Frontiers in Microbiology

Received: 28 June 2021 Accepted: 25 August 2021 Published: 01 October 2021

Citation:

Runa V, Wenk J, Bengtsson S, Jones BV and Lanham AB (2021)

Bacteriophages in Biological Wastewater Treatment Systems: Occurrence, Characterization, and

Function.

Front. Microbiol. 12:730071 doi: 10.3389/fmicb.2021.730071
Phage bacteria interactions can affect structure, dynamics, and function of microbial communities. In the context of biological wastewater treatment (BWT), the presence of phages can alter the efficiency of the treatment process and influence the quality of the treated effluent. The active role of phages in BWT has been demonstrated, but many questions remain unanswered regarding the diversity of phages in these engineered environments, the dynamics of infection, the determination of bacterial hosts, and the impact of their activity in full-scale processes. A deeper understanding of the phage ecology in BWT can lead the improvement of process monitoring and control, promote higher influent quality, and potentiate the use of phages as biocontrol agents. In this review, we highlight suitable methods for studying phages in wastewater adapted from other research fields, provide a critical overview on the current state of knowledge on the effect of phages on structure and function of BWT bacterial communities, and highlight gaps, opportunities, and priority questions to be addressed in future research.

Keywords: bacteriophages, microbial ecology, wastewater treatment, microbial communities, viruses

\section{INTRODUCTION}

Bacteriophages, or phages, i.e., viruses that infect prokaryotic organisms, such as bacteria, play an important role in the ecology and evolution of microbial communities. Phage interaction with prokaryotes can influence the composition (Weinbauer and Rassoulzadegan, 2004; Suttle, 2007), function (Thingstad, 2000; Calero-Cáceres et al., 2019), and evolution (Poullain et al., 2008; Koskella and Brockhurst, 2014) of a microbiome. This interaction has been exploited to control microbial growth in environmental, engineered, and medical fields (Nakai and Park, 2002; Lin et al., 2017; Svircev et al., 2018).

Phages are approximately 1 to 2 orders of magnitude smaller than bacterial cells, commonly ranging in size from $20 \mathrm{~nm}$ to $200 \mathrm{~nm}$, with giant phages measuring up to $600 \mathrm{~nm}$ (Holt et al., 1994; Iyer et al., 2021). They have a simple structure, consisting of a protein capsid containing the phage genome, either single- or double-stranded DNA or RNA (Sharp, 2001; Hatfull and 
Hendrix, 2011), sometimes with a lipid membrane within the capsid surrounding the genetic material (Lundstrom et al., 1979; Kivelä et al., 2002). Phages usually present a lytic infection cycle that starts with the phage adhering to the bacterial cell wall and injecting its genome into the host. A lytic infection leads to the synthesis of new progeny virions, i.e., infective viral particles, which are released upon lysis of the host cell. However, the phage genome might be incorporated into the bacterial genome without causing lysis of the host. This infection is named lysogenic and expression and releasing of virions only occurs if the host is subjected to an external stress (Adams, 1959; Weinbauer, 2004). Depending on the host's growing and environmental conditions, life cycles variations can be observed (Duerkop et al., 2012; Howard-Varona et al., 2017; Ogilvie and Jones, 2017).

Engineered biological systems are central to many environmental applications, including treatment of wastewater and production of bioenergy carriers. Wastewater treatment relies on engineered microbiological processes for biological carbon and nutrient removal, such as suspended growth processes (e.g., activated sludge), attached growth and biofilm processes (e.g., trickling filters, moving bed biofilm reactors, and aerobic granular sludge), and anaerobic digesters, defined here as biological wastewater treatment systems (BWT; Henze et al., 2008).

The role of phages in BWT has been of increasing interest to assess phage impact on bacterial consortia and consequently process efficiency and effluent quality (Withey et al., 2005; Shapiro et al., 2010; Wu et al., 2017). However, it has not been studied to the same extent as for other ecosystems, such as marine (Breitbart et al., 2018) and freshwater environments (Palermo et al., 2019), soil (Pratama and van Elsas, 2018), and the human body (Ogilvie and Jones, 2017), particularly in health-related contexts (Lawrence et al., 2019; Principi et al., 2019). More knowledge on the identity, abundance, and role of phages in BWT may allow more robust and efficient operation, one of the key challenges to achieve target levels of wastewater treatment and potentiate water reuse.

This work focuses on phages in BWT and their interaction with microbial communities central to wastewater treatment. Enteroviruses and pathogen indicators are not included in this review and are reviewed elsewhere (Fong and Lipp, 2005; Farkas et al., 2020). To encourage future research on BWT phages, this review discusses methods based on best practice from phage research in other environments ("Methods to Study Phages in BWT Systems"). We then review available knowledge on phage ecology in BWT ("Phages Identified in BWT Processes") and identify the gaps and opportunities that should lead future research ("Challenges and Opportunities for Studying Phages in BWT Systems").

\section{METHODS TO STUDY PHAGES IN BWT SYSTEMS}

A BWT grab sample can be directly used for analysis of phages. However, usually phages are separated from bacteria and other suspended solids by a series of recovery and pre-treatments to obtain a phage suspension. After phage recovery, multiple methods can be used for identification, quantification, and characterization of their activity, as summarized in Table $\mathbf{1}$. As there is no single methodological pipeline for the isolation and characterization of phages, we propose the most suitable methods to be applied to BWT samples.

\section{Methods for the Recovery of Phages From BWT Processes}

Recovery of Phages From Environmental Samples

Recovery of viruses from environmental samples consists of a series of filtration and centrifugation steps to remove suspended particles, such as sediments, bacteria, and multicellular organisms (Figure 1). The resulting sample should yield a contaminantreduced viral suspension and can be further purified or concentrated.

Although composition of BWT samples varies depending on the influent and type of treatment, they usually have a high concentration of suspended solids that need to be removed. Processing should include decanting or sieving to remove coarse-suspended solids. Centrifugation between 5,000 and $10,000 \mathrm{~g}$ for 10 to $30 \mathrm{~min}$ (Shahin et al., 2019) or filtration with polymeric membranes at $0.45 \mu \mathrm{m}$ removes smaller suspended solids and most prokaryotic cells (Logan et al., 1980; Sullivan et al., 2003). A second filtration step at $0.22 \mu \mathrm{m}$ removes remaining bacteria, with possibility of larger phages to be retained as well. For large volume samples or when concentration of the viral suspension is required, tangential flow filtration or gradient centrifugation can be used (Clokie and Kropinski, 2009; Thurber et al., 2009; Kleiner et al., 2015).

\section{Pre-treatment Methods for Recovery of Phages From Complex Matrices}

Samples with complex matrices, such as activated sludge or anaerobic sludge from BWT, may require additional pre-treatment steps to obtain a phage suspension. Phage adsorption is controlled by the sample's ionic environment, and therefore, its desorption can be induced by changing the $\mathrm{pH}$ and ionic strength (Adams, 1959; Sadeghi et al., 2011). This change can be made by using buffer solutions or surfactants, sometimes combined with physical treatment (Danovaro et al., 2001; Williamson et al., 2003, 2005; Reyes et al., 2010; Hoyles et al., 2014).

Selection of pre-treatment should consider phage distribution across liquid, suspended, and solid phases. Failing to recover phages attached to free bacteria or lodged within flocs, aggregates and biofilms can lead to an underestimation of their quantity and recovery of a non-representative sample (Motlagh et al., 2015; Wu et al., 2017). In fact, it is estimated that over $97 \%$ of the phages in activated sludge are adsorbed into suspended solids (Ketratanakul and Ohgaki, 1989). Beef extract solution, potassium citrate, and phosphate solutions have been used as buffers for recovery of viruses from activated sludge from lab-scale systems (Khan et al., 2002a; Motlagh et al., 2015) and from activated and anaerobic sludge samples from full-scale systems (Wu and Liu, 2009). However, beef extract has been associated with interference in downstream analyses of phages, e.g., in fluorescence microscopy (Katayama et al., 2002; Williamson 


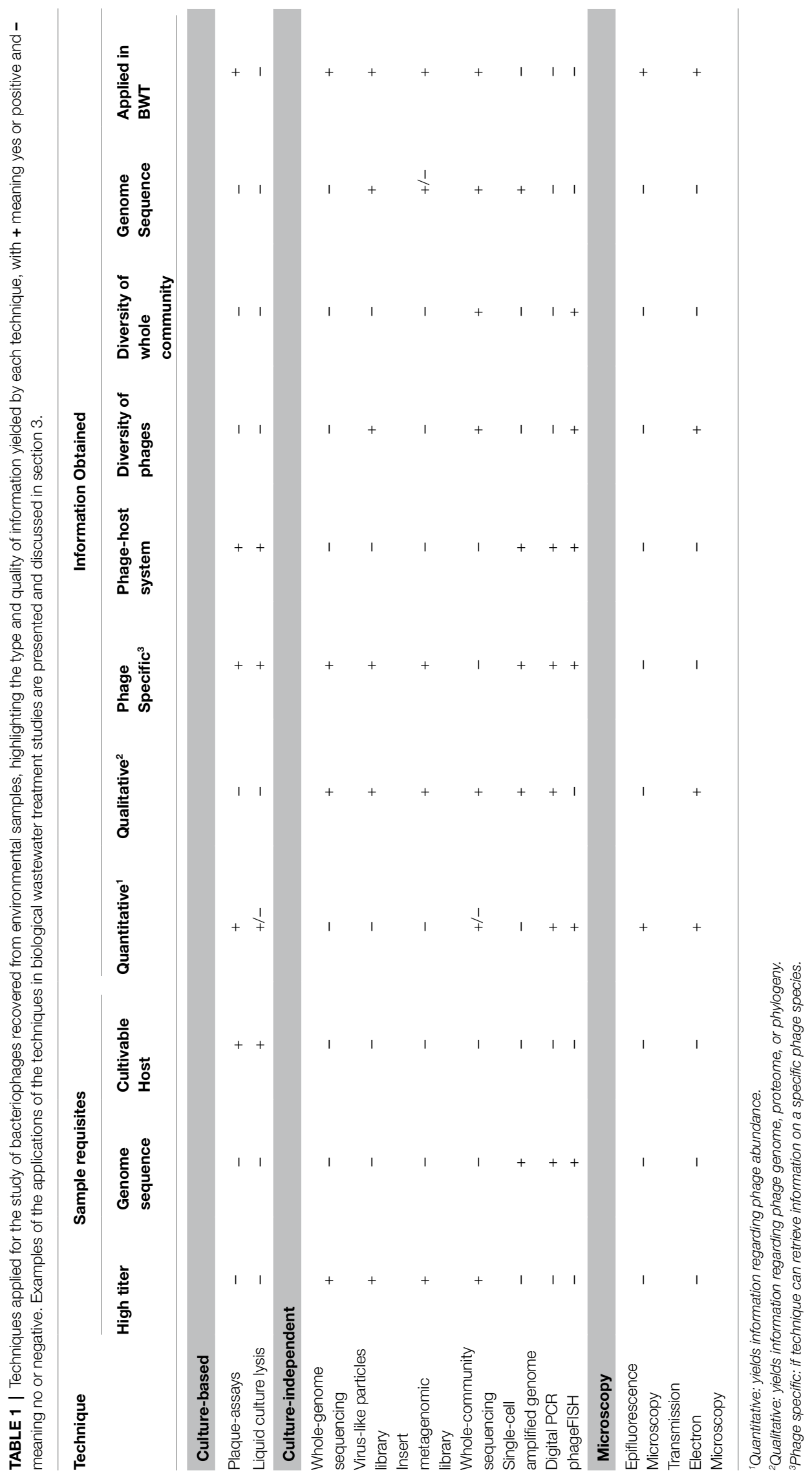




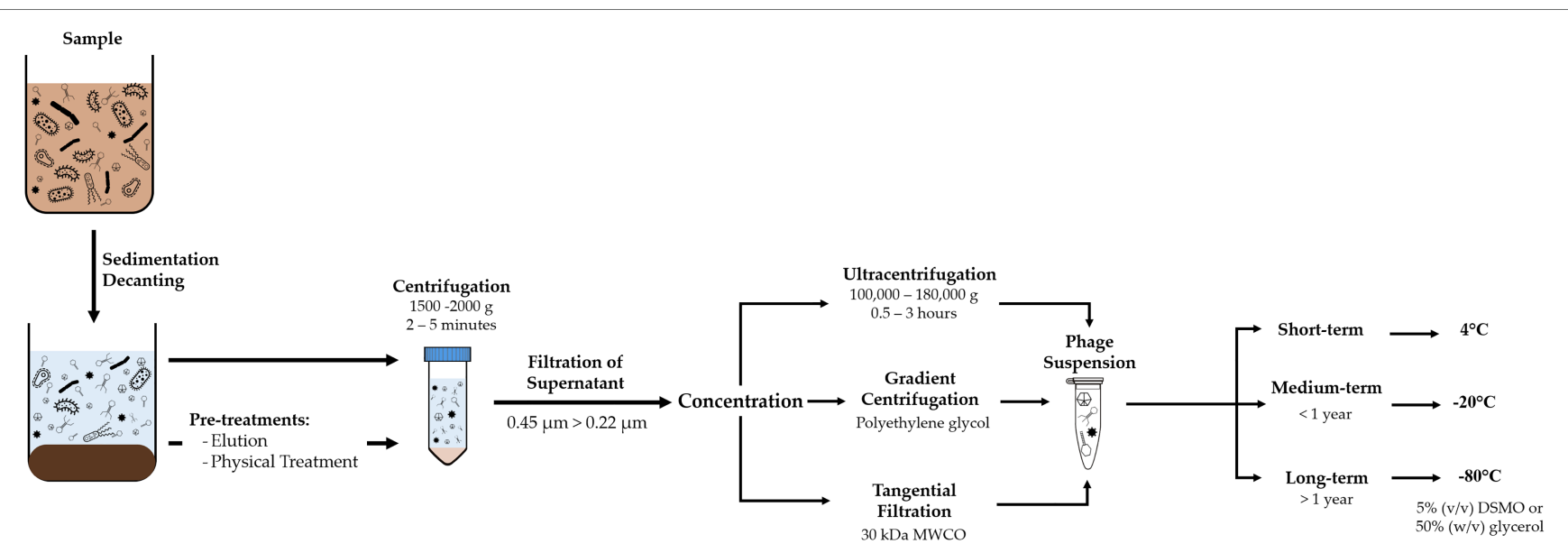

FIGURE 1 | Diagram of methodology for recovery of viruses from environmental samples, comprising removal of suspended solids and concentration of the phage suspension, and adequate storage conditions according to time frame.

et al., 2003). A combination of physical and chemical pre-treatments can enhance phage recovery (Monpoeho et al., 2001).

To optimize extraction and recovery of phages, more research is needed on how the flocs and granules' structure hinders phage recovery and what are the prevailing chemical and physical interactions between phages and activated sludge bacteria.

\section{Storage of Phage Suspension}

Grab samples or recovered phage suspensions should be processed as soon as possible or stored at $4^{\circ} \mathrm{C}$ to minimize deterioration of phage viability (Clokie and Kropinski, 2009). Phages can be suspended in the working buffer or in $1 \%(\mathrm{v} / \mathrm{v})$ chloroform to improve sample stability (Mohiuddin and Schellhorn, 2015; Fan et al., 2019). However, chloroform can damage the lipids within the capsid and cause inactivation of some phages and should be avoided when the type of phages is unknown or whole viral communities are to be studied (Clokie and Kropinski, 2009). Samples can be stored at $4^{\circ} \mathrm{C}$ for short periods of time without significant loss of phage numbers and activity, at $-20^{\circ} \mathrm{C}$ for short/medium term storage, with possible addition of preservative agents, and cryopreserved at $-80^{\circ} \mathrm{C}$ for long term storage with $50 \%(\mathrm{w} / \mathrm{v})$ glycerol or $5 \%(\mathrm{v} / \mathrm{v})$ DMSO. However, freezing and freeze-thaw cycles can decrease both phage concentration and activity and introduce bias in subsequent analysis or experiments (Suttle et al., 1991; Thurber et al., 2009).

\section{Isolation of Phages}

Conventional culture-based methods to isolate phage require the growth of host bacterial species as pure cultures, to support the replication of the desired phage. Isolation of a specific phage permits detailed studies of bacteria-virus interactions, infection patterns, and host-phage coevolution (Clokie and Kropinski, 2009; Hyman, 2019).

After recovery and purification, the phage suspension might contain the target phage but likely in low numbers. Suspensions can be incubated with a pure culture of the prospective bacterial host as an enrichment step to promote phage propagation and obtain higher concentrations (Figure 2; Clokie and Kropinski, 2009; Bonilla et al., 2016). The resulting phage suspension can be used as inoculum for a plaque-assay (Adams, 1959; Clokie and Kropinski, 2009; Hyman, 2019) by either directly applying the suspension into a lawn of the bacterial host or by using the double-agar/agar overlay method (Hantula et al., 1991; Lee et al., 2006). For lytic infections, as the phage progeny is released and infects neighboring bacterial cells, a transparent plaque visible to the naked eye is formed. Often plaques have varying morphologies that are likely formed by different types of phages present in the environmental sample. For purification of individual phage types, material from a single plaque is used to infect a fresh host culture, and the enrichment and plaque passage are repeated multiple times until all plaques observed in a plate have the same morphology, to ensure the isolation of a single phage species.

Culture-based methods were applied for phage isolation from lab-scale and full-scale enhanced biological phosphorus removal (EBPR) systems (Khan et al., 2002b; Lee et al., 2004, 2006) and full-scale activated sludge plants (Fan et al., 2017, 2019). Further examples on isolation of phages from BWT systems are provided in "Phages Isolated From BWT Systems." Quantification of isolated phages is routinely done by plaque-assays and determined as plaque forming units per volume (Figure 3) but alternative techniques for phages quantification are described in "Analysis of Phages Genome" and "Uses of Microscopy to Quantify and Characterize Phage Morphology."

Phages causing a lysogenic infection, also described as temperate phages, can be challenging to investigate through plate-based assays as they do not always readily replicate or produce a plaque and can be difficult to propagate in the enrichment steps. To induce prophage replication and virions release, stress factors, such as antibiotics or DNA compromising agents, including mutagenic compounds, such as mitomycin-C (Choi et al., 2010; Motlagh et al., 2015) and radiation (Clokie and Kropinski, 2009), can be applied to the host cells. 


\section{Phage Isolation}

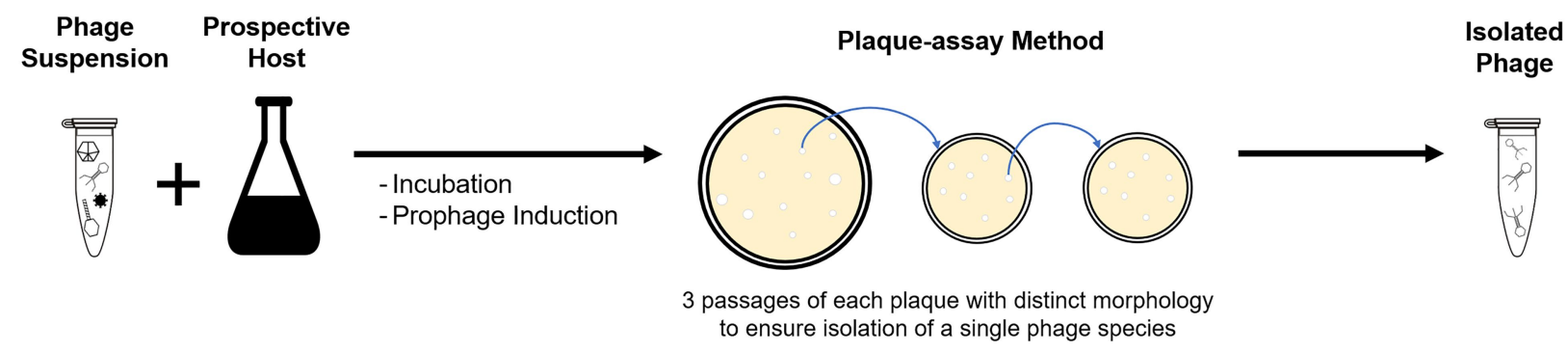

FIGURE 2 | Methodology for bacteriophage isolation: The bacteriophages recovered from environmental samples are incubated with the prospective bacterial host and used to inoculate a plaque-assay; the procedure is repeated using material of a single plaque to ensure isolation of individual phage types.

\section{Phage Quantification}

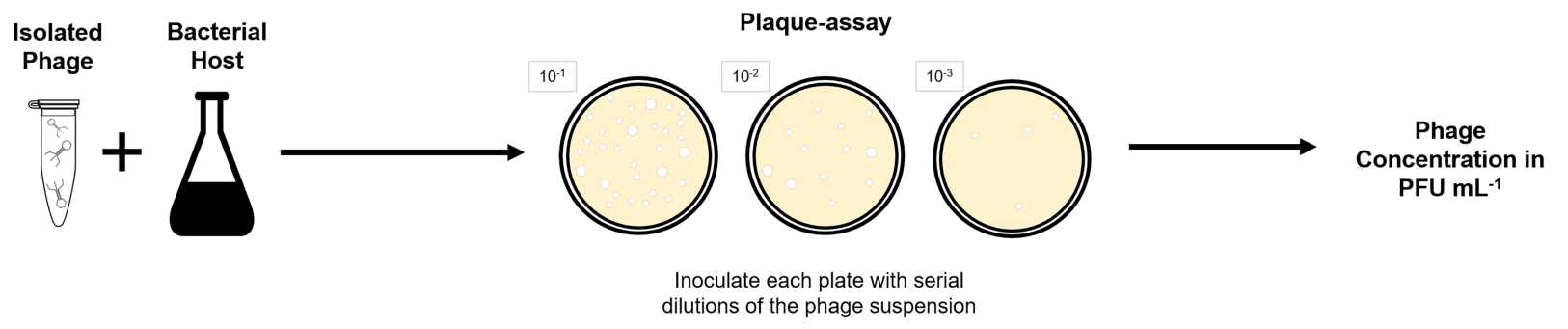

FIGURE 3 | Plaque-assay method can be used to determine the concentration of a phage suspension in plaque forming units per volume, in which each plaque is considered to be originated by one single phage.

\section{Analysis of Phages Genome}

Genetic analysis of isolated phages can reveal information about phage life cycle and interaction with the bacterial host. Genome sequencing is also valuable information that can be published and help unveil the diversity and role of phages in BWT. Genome information of phages is accessed via genetic sequencing. The first step involves DNA and/ or RNA extraction and purification, following established protocols (Green and Sambrook, 2012; Iker et al., 2013; Jakociune and Moodley, 2018). Various sequencing methods, e.g., Illumina sequencing (Rihtman et al., 2016), Ion torrent (Marine et al., 2020), or pyrosequencing (Becker et al., 2012), can be applied for phages following standard procedures developed for bacteria characterization. Bioinformatic tools enable the assembly the sequencing reads and comparison against genome databases, such as GenBank, EMBL, and DDBJ (Hatfull and Hendrix, 2011; Walker et al., 2018). Phage specific databases, such as PhagesDB, are also available (Lima-Mendez et al., 2007; Leplae et al., 2010; Russell and Hatfull, 2017). Some studies on the isolation of phages from BWT carried out genomic analysis, as further discussed in "Phages Isolated From BWT Systems" (Petrovski et al., 2011a,b, 2013, 2014; Khairnar et al., 2014; Liu et al., 2015; Fan et al., 2019).
Obtaining the phage genome is necessary for the identification of functional genes but also enables other analysis. For instance, it permits the assigning of phages to viral families. Viruses taxonomy is an evolving area with an increasing number of phage genomes being added to databases and continuous evaluation of established taxonomic groups (Hatfull and Hendrix, 2011; Tolstoy et al., 2018). Viral taxonomy still has some challenges, such as lack of universally conserved phylogenetic markers in phage genomes (analogous to 16s rDNA in bacteria) or adaptation of available methods to smaller genomes, which consequently deters the unveiling of phage diversity in BWT. Knowing a phage genome can too enable its quantification. If the phage genome is known, fluorescence quantitative polymerase chain reaction using targeted PCR primers tagged with a fluorophore can be used to detect and quantify the phage (Imamovic et al., 2010; Flannery et al., 2013; Kitajima et al., 2014). The limited knowledge on phages found in BWT hinders the design of suitable primers, restricted to the known sequences (Girones et al., 2010; Bibby et al., 2019), and biases during genome amplification, such as uneven coverage of viral genomes, over-amplification of dominant groups, and limitation to dsDNA template, need to be considered for accurate quantification (Kim et al., 2013a; Brinkman et al., 2018). 


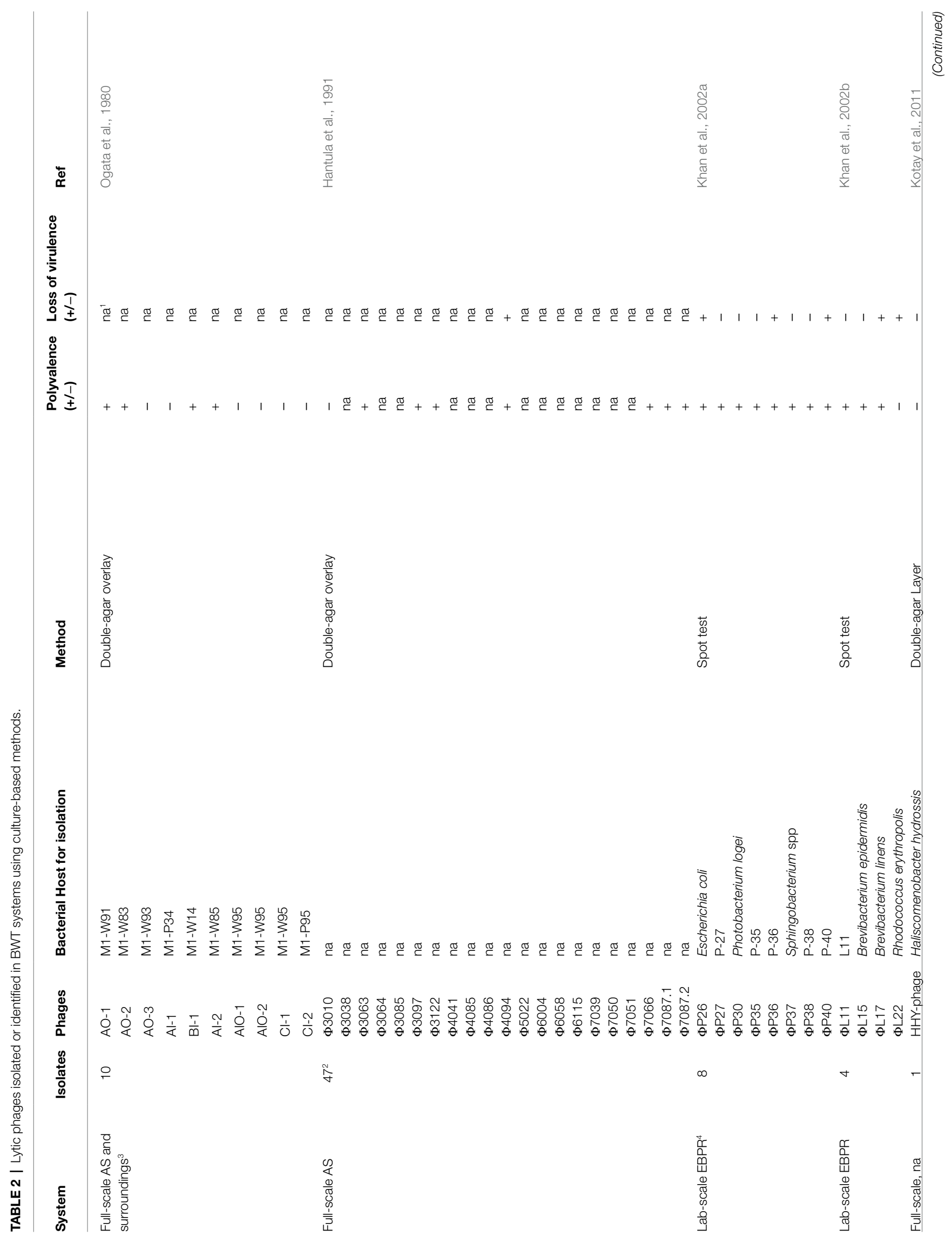




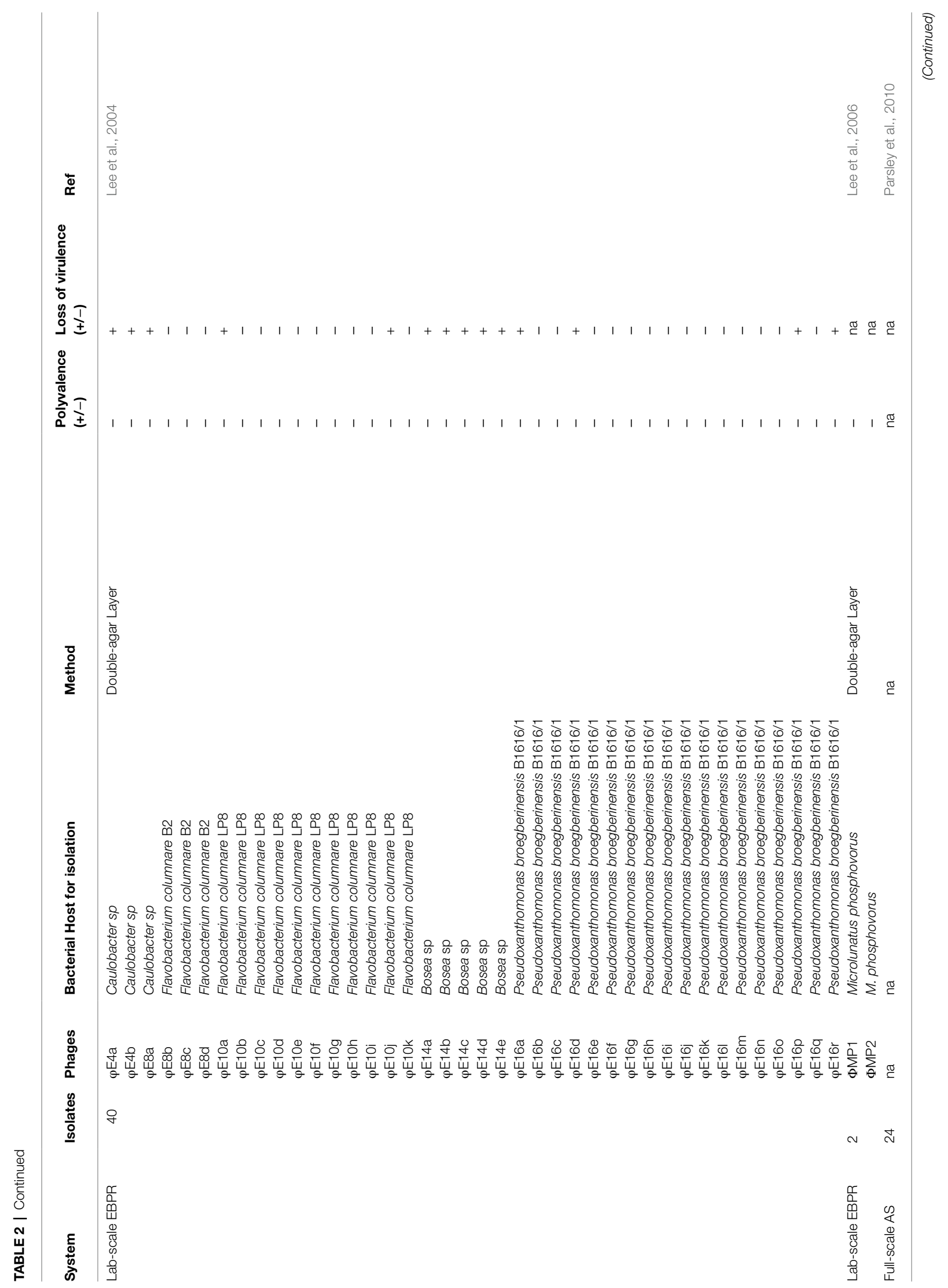




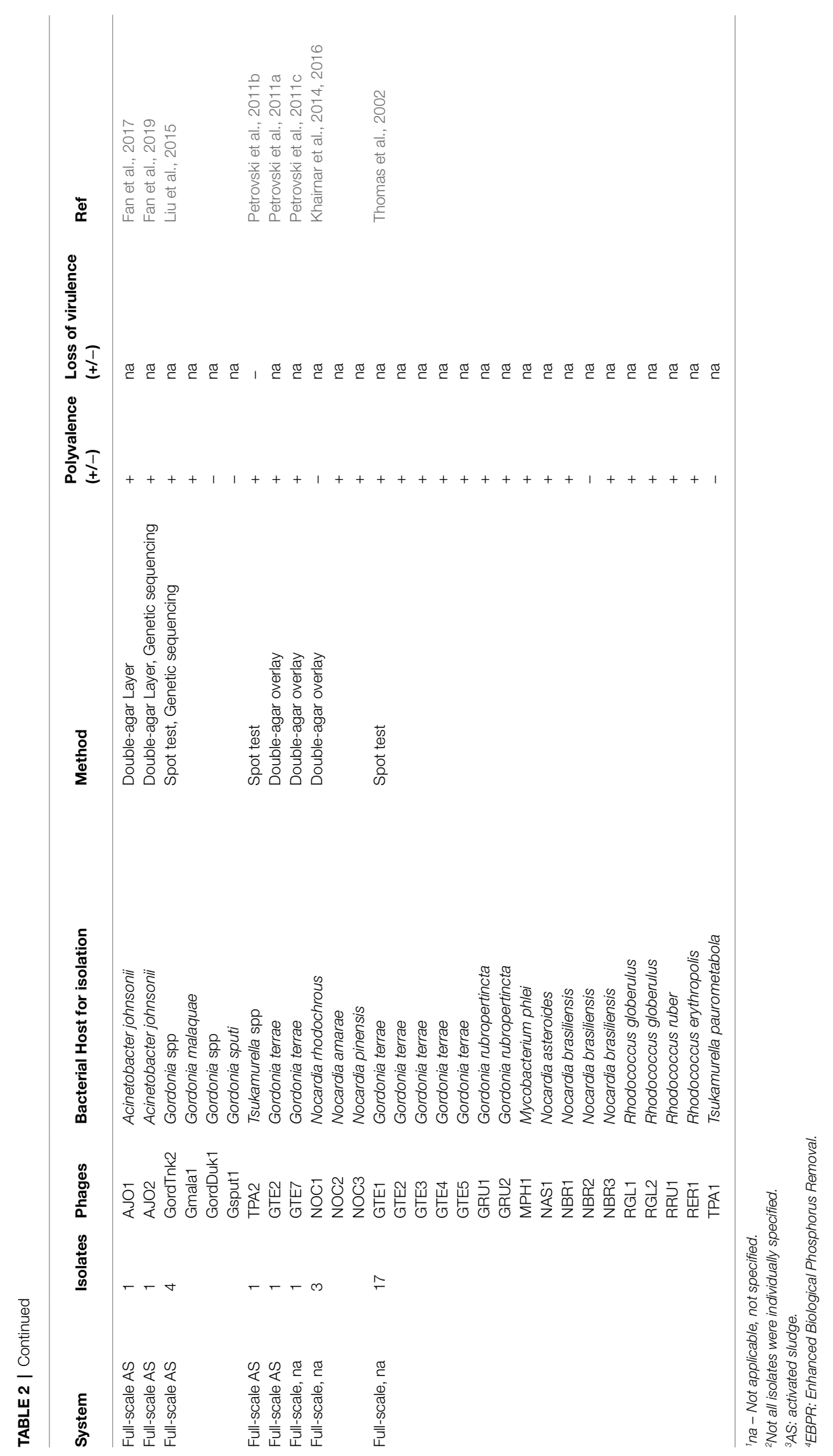


Although genome sequencing and analysis is not fully explored in published studies (Table 2), they represent important opportunities for future phages isolated from BWT systems.

If phage isolation is not possible or a more comprehensive overview of the phage community is intended, metagenomics can be applied to analyze all nucleic acids recovered from an environmental sample, providing a global assessment of diversity and distribution of phage communities as whole (Angly et al., 2006; Reyes et al., 2013a; Brum and Sullivan, 2015). The application of metagenomics methods starts with the extraction of the total DNA or RNA from either the microbial community or just from the recovered and purified virus particles (Thomas et al., 2012; Culligan et al., 2014). Then, a library is constructed from purified nucleic acids, as reviewed elsewhere (Solonenko and Sullivan, 2013). These are sequenced and aligned with reference databases to identify coding sequences (Kim et al., 2013b; Kelleher et al., 2015). Two different approaches are used within metagenomics to study uncultured organisms. The first employs amplicon sequencing, a targeted technique where primers are used to amplify gene variants of interest from DNA extracts, such as $16 \mathrm{~S}$ ribosomal RNA genes for prokaryotes. The amplified DNA is then sequenced to obtain coverage of the variants in a population (Pérez-Losada et al., 2020). However, there is no identified genetic marker or conserved sequence for phages and the inability to design primers for phages with unknown sequences compromises an accurate identification of phages and their phylogeny (Angly et al., 2005; Gilbert and Dupont, 2011). Alternatively, shotgun sequencing covers all nucleic acids in a sample (Hayes et al., 2017). Comparative analysis of phage genome constitutes another challenge due to limited availability of viral sequences in databases, and interference of bacterial DNA with viral nucleic acids (Roux et al., 2013; Hayes et al., 2017). Application of these methods in the context of BWT is discussed in "Effects of the Phage Population on Microbial Communities and BWT Performance."

\section{Uses of Microscopy to Quantify and Characterize Phage Morphology}

Microscopy does not require phage cultivation or isolation and provides information on their morphology and abundance, which can be useful to characterize and infer about phages life cycle and study the population dynamics in a given system.

Provided phage concentration is high enough for sample preparation, morphology and component size can be determined by transmission electron microscopy (TEM), a technique well established, relatively simple to perform, and that reveals unique information over other approaches (Adams, 1959; Ackermann, 2012). TEM has been used to observe morphology of phages isolated from BWT and classify phages into viral families (Lee et al., 2006; Liu et al., 2015; Fan et al., 2017). We encourage the use of TEM to complement the information obtained by genome sequencing and correctly characterize the phages, highlighting that it can also be used to visualize non-cultured phages (Ackermann, 2012; Richert-Pöggeler et al., 2019).

Phages can be quantified via fluorescence-based microscopy or cell counting when stained with a fluorophore (Figure 4; Wen et al., 2004; Pollard, 2012). Common fluorescent stains are SYBR Green I and II ad SYBR Gold (Shibata et al., 2006; Patel et al., 2007). However, staining does not discriminate

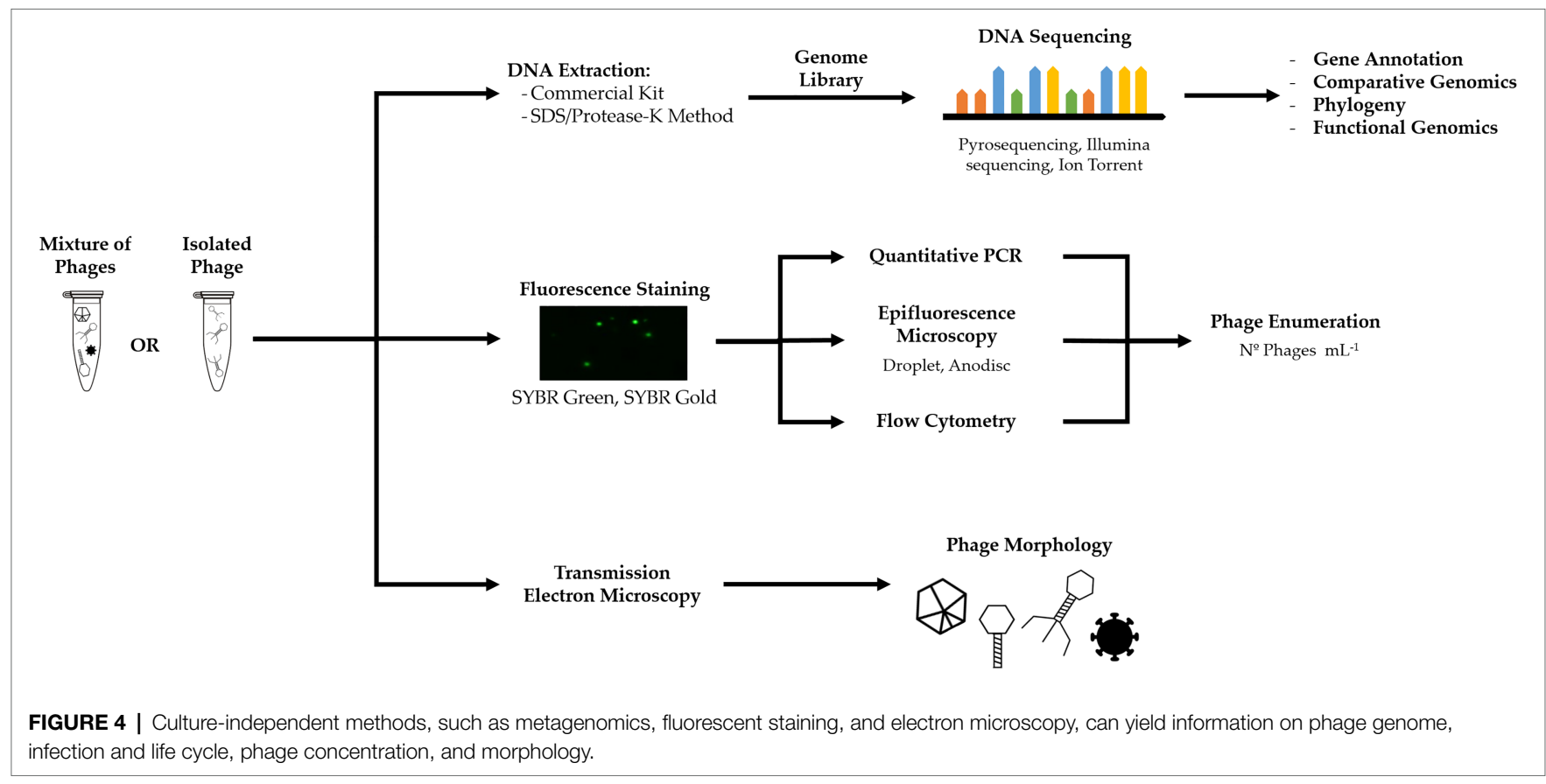


between phages and other viruses and provides the total number of viral particles in a sample. Occurrence of free DNA can also contribute to an overestimation of phages (Patel et al., 2007; Clokie et al., 2011).

In BWT research, epifluorescence microscopy has been used for the quantification of viruses from full-scale treatment plants (Otawa et al., 2007; Wu and Liu, 2009; Yang et al., 2017) and lab-scale EBPR reactors (Barr et al., 2010; Motlagh et al., 2015). Fluorescence flow cytometry using SYBR Green staining has also been applied for quantification of viruses from activated sludge samples, benchmarked with TEM counts (Brown et al., 2015, 2019). Although other viruses and eukaryotic pathogens can be found (Aw et al., 2014), it is assumed that the majority of viruses in bacteria-rich environments, such as activated sludge, are phages, as these need an active host to propagate and thrive in the system (Payan et al., 2005; Jofre et al., 2014). Nonetheless, it is not possible to make an accurate quantification of all phages in a viral or microbial community.

\section{PHAGES IDENTIFIED IN BWT PROCESSES}

The presence of phages in activated sludge was first confirmed in 1965 (Dias and Bhat, 1965). Later, activity of phages was correlated to decreasing concentration of its bacterial host in activated sludge (Ogata et al., 1980) while comparison of phage concentration in the influent and along a wastewater treatment plant suggested phage production occurred in the activated sludge tank (Ewert and Paynter, 1980). The average concentration of viral-like particles (VLP) in BWT processes ranges from $10^{7} \mathrm{VLP}$ $\mathrm{ml}^{-1}$ to above $10^{9} \mathrm{VLP} \mathrm{ml}{ }^{-1}$ which is comparable to the concentration of $10^{8}$ to $10^{9}$ VLP $g^{-1}$ feces in the human gut (Kim et al., 2011) but two orders of magnitude higher than the values reported for marine environments (Breitbart et al., 2018), groundwater (Pan et al., 2017), and freshwater systems (Filippini and Middelboe, 2007).

Research on phage ecology of BWT has applied both culture-based and culture-independent methods, but many knowledge gaps remain on the abundance and composition of phage community in BWT and factors that can contribute to their interaction with the microbial community, particularly with bacteria performing key functions. Additional studies are necessary to frame more comprehensive insights, with scope for emerging technologies to be used. With increasing evidence of the effect of phages in BWT being reported (discussed in "Effects of the Phage Population on Microbial Communities and BWT Performance"), they may have a more significant role in BWT communities than what has been considered so far.

\section{Phages Isolated From BWT Systems}

Culture-based methods have been the main technique used to identify phages in BWT systems. In early studies on full-scale activated sludge systems, 10 phages from an aeration tank and surroundings were isolated, using two different bacterial strains isolated from the sludge as prospective hosts (Ogata et al., 1980). A similar screening studied 49 phagehost systems occurring in an aeration basin at a municipal wastewater treatment plant (Hantula et al., 1991). More recently, phages have been isolated from full-scale (Fan et al., 2017, 2019) and lab-scale BWT systems (Khan et al., 2002a,b; Lee et al., 2004, 2006). Different phages infecting foamformation associated filamentous bacteria from the genera Dietzia, Gordonia, Nocardia, Rhodococcus, Tsukamurella, Haliscomenobacter, and Mycobacterium have been isolated (Thomas et al., 2002; Kotay et al., 2011; Khairnar et al., 2014), sequenced (Petrovski et al., 2011a,b,c, 2012, 2013; Liu et al., 2015), and respective host range studied (Petrovski et al., 2011a,c). Similarly, culture-based methods are the standard in the determination of a phages' host range, with screening of phages against prospective hosts (Figure 5), and have been used to study the host range of phages isolated from BWT samples (Thomas et al., 2002; Lee et al., 2006; Fan et al., 2019).

As shown in Table 2, studies of phage isolation from BWT systems are still limited. Despite the limitations of culturebased methods, such as loss of virulence (Hantula et al., 1991; Khan et al., 2002a,b) or changes in polyvalency - the ability to infect multiple hosts (Ogata et al., 1980; Thomas et al., 2002; Weinbauer, 2004) - (see "Challenges and Opportunities for Studying Phages in BWT Systems"), the conventional,

\section{Host Range}

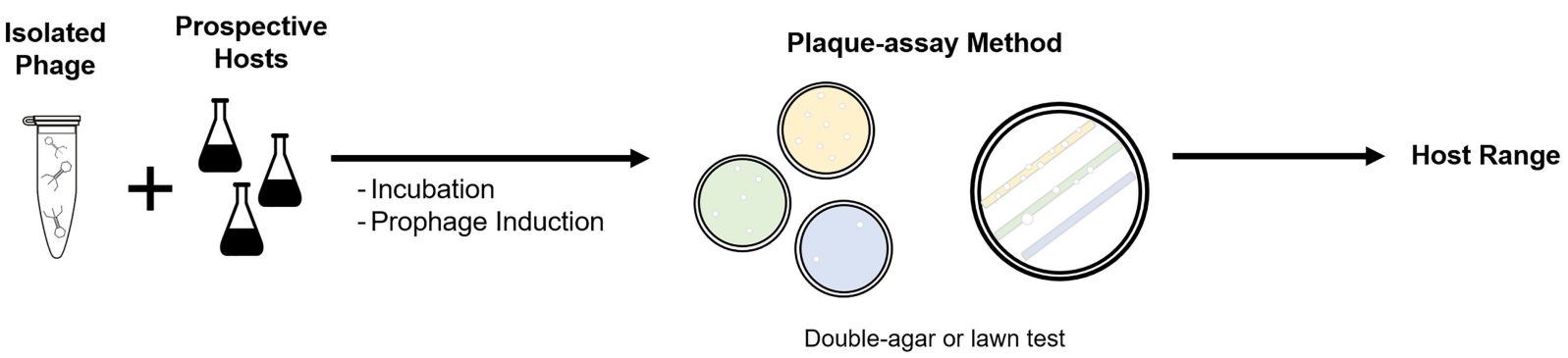

FIGURE 5 | Plaque-assay method can be used to determine the host range of isolated phages by incubating the bacteriophages with selected prospective hosts. 
straight-forward methods for isolation could be more widely applied.

\section{Effects of the Phage Population on Microbial Communities and BWT Performance \\ Diversity of Phages in BWT Systems}

Metagenomics are increasingly used to investigate microbial communities as a whole (Mizuno et al., 2013; Brum and Sullivan, 2015) and have been applied to study the virome diversity in BWT. These culture-independent methods can be used alone or to complement culture-based methods (Figure 4). Although phages are likely the dominant types of viruses in BWT environments (Weitz, 2015), it is not always possible to selectively count or identify phages among the viral population, including enteric or archaeal viruses. Therefore, the term viruses will be used when the methods applied do not enable this distinction. The overall diversity of phages found in wastewater treatment plants is lower that the diversity in marine environments, similar to the diversity, found in soils but higher than the viral diversity in human feces (Tamaki et al., 2012). Abundance and diversity of phages typically change in different ways along the process. The virus load of raw sewage has been estimated at $10^{8}$ viral particles $\mathrm{ml}^{-1}$ (Wu and Liu, 2009; Brown et al., 2019). Concentration of viruses increases in the secondary treatment units to about $10^{9}$ viral particles $\mathrm{ml}^{-1}$ in activated sludge processes (Otawa et al., 2007; Wu and Liu, 2009) and $10^{10}$ viral particles $\mathrm{ml}^{-1}$ in anaerobic digesters (Tamaki et al., 2012), followed by lower concentrations found in the effluent (Otawa et al., 2007; Wu and Liu, 2009). The increase in the concentration of viruses in the treatment course is presumably due to the presence of hosts that promote phage propagation (Hantula et al., 1991). The abundance of viruses decreases in the treated effluent, with a concentration of $10^{8}$ viral particles $\mathrm{ml}^{-1}$ (Wu and Liu, 2009). Although no explanation is provided for the observed decrease, it is likely that viruses are removed along with bacteria in the settling stage. The effluent will furthermore have a negligible concentration of prospective hosts when compared to the previous treatment steps. It can be assumed that virus concentrations will be further reduced if tertiary treatment is applied. Different wastewater treatment plants will likely have variations in phage concentrations depending on influent and operational conditions (Otawa et al., 2007; Wu and Liu, 2009; Petrovich et al., 2019). A few studies have used sequencing methods for virome characterization in BWT systems. Comparative metagenomics of viruses in activated sludge found the viral families Myoviridae, Siphoviridae, and Podoviridae, all within the Caudovirales order, at relative abundance of $40.3,31.9$, and $25.6 \%$, respectively (Parsley et al., 2010). Other metagenomics studies on activated sludge (Tamaki et al., 2012; Yang et al., 2017; Petrovich et al., 2019), raw sewage (Aw et al., 2014), and anaerobic digestion (Heyer et al., 2019) also identified these viral families as dominant. However, only about $5 \%$ of the sequences obtained in these studies overlapped with known viral genomes in databases, indicating a unique virome in BWT systems. Despite identification of dominant viral families, the virome significantly differs at genera and species level when comparing bulking and non-bulking activated sludge (Yang et al., 2017) or suspended growth (activated sludge) with attached growth (trickling filters; Petrovich et al., 2019).

Similar treatment systems might share a significant part of their phage population including a characteristic genomic fingerprint, i.e., a common or established core of phages characteristic of a treatment process or geographic area, as observed in a study of the viral genome of 14 wastewater treatment plants (Otawa et al., 2007). This is observed for prokaryotic communities of BWT worldwide sharing a common core of organisms (Wu et al., 2019), with differences in some bacterial groups depending on processes and operation mode (Wagner and Loy, 2002; Jo et al., 2016). Furthermore, if metagenomic studies include the analysis of the bacterial genome, fingerprints will then include not only "free" phages but also prophages (Parsley et al., 2010; Petrovich et al., 2019). Establishing a genomic fingerprint can also help addressing questions regarding dynamics in phage-host systems, decline of certain key functional bacteria, and migration of phages within the system.

Metagenomics can produce valuable data which continuously endorses the improvement of genome analysis, expansion of databases, and the identification of patterns in phage abundance and diversity. This information can provide evidence on the uniqueness of BWT phage community and assist with building a useful viral fingerprint for process monitoring and control (Hatfull, 2008), as further discussed in "Challenges and Opportunities for Studying Phages in BWT Systems."

\section{Dynamics of Phage and Bacterial Populations}

The type of infectious cycle affects bacterial population dynamics and function differently. Lytic infection can result in sharp decreases in the number of bacterial cells (Thingstad, 2000; Maslov and Sneppen, 2017), while a lysogenic infection proceeds without affecting cell numbers, with the prophage remaining latent within the bacterial genome (Howard-Varona et al., 2017; Monteiro et al., 2019). However, multiple variations of these life cycles can be found in nature.

It has been demonstrated in lab-scale BWT systems that phages can shape microbial communities and process performance. For example, Microlunatus phosphovorus concentration in an activated sludge reactor decreased upon phages supplementation (Lee et al., 2007). Sudden failure of a EBPR reactor fed with synthetic wastewater and enriched in Accumulibacter was attributed to an infection (Barr et al., 2010). Phosphorus removal of analogous well-performing EBPR systems deteriorated when infected with recovered phages from the original reactor, verifying phage infection over operational conditions or microbial competition as cause of deterioration. In another EBPR system, prophages were induced with chemical stress factors to adopt a lytic cycle, causing a decrease of Accumulibacter spp. abundance along with a decrease on phosphate uptake and release (Motlagh et al., 2015).

Similar dynamics between endogenous phage and bacterial populations were observed in full-scale systems. In a membrane bioreactor treating industrial wastewater, phage concentration 
was inversely correlated with both the original bacterial hosts and phylogenetically related bacteria (Shapiro et al., 2010). An increase of bacteria concentration in a bulking activated sludge was concurrent with a decrease in phages concentration and diversity (Yang et al., 2017). In a nitrification process, a significant correlation between increasing virus number and decreasing total bacteria number was found. The same study showed that virus numbers were significantly influenced by $\mathrm{pH}$ and magnesium ions which affect the adsorption of phages to the host (Brown et al., 2019). However, when viruses of 14 different wastewater treatment plants were supplemented to virus-free lab-scale reactors fed with synthetic wastewater (Otawa et al., 2007), phage-host interactions led to relatively slow changes in virus numbers, suggesting a combined effect of lysogenic infections, bacterial resistance, and sludge properties.

Although lytic infections are more easily identified by the steep decrease in host numbers, prophage inclusion in the host genome can benefit the host and indirectly regulate the propagation of other bacteria. For instance, prophage inclusion may grant the host resistance to infection by other phages (Fortier and Sekulovic, 2013), facilitating host growth and pathogenicity (Duerkop et al., 2012; Fortier and Sekulovic, 2013), increasing resistance to multiple stress conditions (Bossi et al., 2003; Wang et al., 2010), and providing advantage in the competition against other bacterial strains (Duerkop et al., 2012; Fortier and Sekulovic, 2013). Rather than causing the decline of the infected population, prophages can instead promote resilience and stability of the bacterial strain in the community, as shown for the gut microbiome (Breitbart et al., 2003, 2008; Kim et al., 2011). It was shown that lytic infections can decrease the production rate of biogas in an anaerobic digester, while facilitating the growth of auxotrophic organisms by increasing nutrient cycling through cell lysis (Heyer et al., 2019). There is also very little information available on how lysogenic activity is regulated in BWT systems, with environmental factors and different pollutants being likely to induce lysogenic cycle (Howard-Varona et al., 2017).

It is still unclear what are the phage-host dynamics in BWT ecology and how significant this impact is on the operation of full-scale communities, e.g., if the affected bacteria would be replaced by other functional organisms or if the development of resistance by the hosts would characterize an arms race of fluctuating-selection model. Without this information, the modeling and control of BWT are lacking a fundamental element.

\section{Use of Specifically Isolated Phages for Bacterial Population Control}

Lytic phages have potential as biological tools to control bacterial populations. In the context of BWT, phages have been successfully used to control detrimental sludge bulking and foaming in lab-scale systems (Thomas et al., 2002; Withey et al., 2005). Lytic phages have been shown to decrease activated sludge bulking and foaming and to improve process performance by controlling bacteria detrimental to the process (Thomas et al., 2002; Withey et al., 2005). Added phages were able to control foam forming Haliscomenobacter hydrossis, without impacting nutrient removal while improving sludge settling properties (Kotay et al., 2011). A mixture of four phages could repeatedly decrease a Gordonia population by $90 \%$ (Liu et al., 2015). Similarly, addition of three phages infecting Nocardia reduced foam production at lab-scale (Khairnar et al., 2016).

Knowledge on the host range is important to design biotechnological applications (Ross et al., 2016; Sharma et al., 2017), as many phages are host specific (Weinbauer, 2004; Poullain et al., 2008) while others can infect a wider range of bacteria across species and genus (Koskella and Meaden, 2013; Ross et al., 2016). Alternatively, a few culture-independent methods are available to study host range and dynamics of phage-host systems, with some techniques developed to study phage infections at a single-cell level, as explained by Dang and Sullivan (2014). Although the techniques described do not require cell cultivation, the information retrieved is restricted by knowledge on the genome of the host and phage of interest and lacks validation and more examples of application (Dang and Sullivan, 2014; Bibby et al., 2019). Even so, they were never applied in the context of BWT and can therefore be an interesting investigation since most bacteria and phages in activated sludge have not been isolated.

Another limitation of the studies on the application of phages as biocontrol agents in BWT is that they all were conducted in lab-scale systems with well-controlled conditions, with microbial communities usually having low diversity. To our knowledge, full-scale testing of phage infection has not been reported but will be necessary for the development of this technology for bacterial population control in BWT. Besides scalability, and as further discussed in "Opportunities and Potential Application of Phages in BWT," it is also necessary to consider a formulation that ensures activity and effectiveness of the applied phages and how to prevent the development of phage insensitive mutants.

\section{CHALLENGES AND OPPORTUNITIES FOR STUDYING PHAGES IN BWT SYSTEMS}

\section{Outlook on Phage Research in BWT}

Challenges for studying phages from BWT samples start at the recovery stage. Activated sludge morphology and sample matrix vary depending on the BWT system. Suspended growth technologies, in which bacteria aggregate in flocs, often have higher concentration of suspended solids in the reactor than attached-growth technologies, but generally up to five times lower than in anaerobic digestion systems (Henze et al., 2008). It is still unknown to what extent the physical and chemical properties of activated sludge can compromise an accurate quantification of phages or, more significantly, the success of infection. For instance, granular sludge could be more robust toward phage infection since bacteria performing essential functions in the process aggregate in dense granules and short wastewater residence time promotes the wash out of phages (Danovaro et al., 2001; Brown et al., 2015; Bengtsson et al., 
2018). Similarly, biofilms in attached-growth BWT systems can delay phage penetration and infection (Simmons et al., 2020). The effect of phage activity on sludge morphology has also not been explored. Expertise from studies in other environments should be applied to BWT considering the resemblance of sample matrix and composition, e.g., samples from activated sludge systems are more like aqueous or sediment samples while sludge from anaerobic digestion can be processed similarly to soil or fecal samples.

Following to the isolation of phages, culture-based methods have a limited scope of analysis. It is estimated that $99 \%$ of all bacteria are yet to be cultivated in lab environments (Rinke et al., 2013). The majority of bacteria from BWT systems has not been isolated (Xia et al., 2018), with many functional organisms only being identified using metagenomic approaches (Nielsen et al., 2019). The impossibility to isolate potential hosts consequently limits the study of phage communities and phages that might be dominant or have pivotal activity in shaping the microbial ecology of a given environment. Even if a prospective host is culturable, other challenges stand before phage isolation. Identifying lysogenic life cycles, which can affect the host populations in different ways (Wang et al., 2010; Reyes et al., 2013b), may require specific media supplementation or culture conditions for induction, which are unknown. Co-evolution of phages and hosts can also lead to the loss of virulence by the phage or development of resistance by the host (Alizon and Van Baalen, 2008; Diard and Hardt, 2017). Bacteria can develop a wide range of mechanisms to avert phage infection at different stages of the process, for instance to inhibit adsorption of the phage to host receptors and the synthesis of intracellular proteins to impede phage genome transcription and maturation (Labrie et al., 2010).

Culture-independent approaches, such as metagenomics, can be used to yield more information about phages in BWT samples but have their own limitations. The diversity of microbial communities is still poorly described. Therefore, many metagenomic analyses of the virome from BWT result in more than $95 \%$ of genome fragments having no homology with genomes deposited on databases (Tamaki et al., 2012; Petrovich et al., 2019). This leaves most of the phage community unidentified. This issue is further accentuated by the lack of genetic markers and the inability to design primers to establish an accurate phage identification and phylogeny (Angly et al., 2005; Gilbert and Dupont, 2011). The extrapolation of the outcomes from both approaches to phages needs to be carefully assessed (Handelsman, 2004; Angly et al., 2006; Hayes et al., 2017). Culture-independent methods are mostly developed and applied for the analysis of double-stranded DNA. Phages with single-stranded DNA and RNA might be excluded in such analysis and it is necessary to adjust the bioinformatics tools for much smaller and simpler genomes (Gilbert and Dupont, 2011; Ogilvie and Jones, 2015). Automatic annotation programs occasionally display false negatives corresponding to undetected genes, false positives for non-coding open reading frames identified as coding, and incorrect start codons assigned (Salisbury and Tsourkas, 2019). These lapses accumulate over time as the genome annotation for new phages relies on previous annotations. Nonetheless, research on phage ecology in BWT is still very limited and with scope to apply well-described culture-based and -independent methods.

When it comes to understanding the dynamics between phages and bacterial populations, the complex and variable nature of the microbial communities, wastewater influent, and operation of BWT extend to the phage-host dynamics. There are three major models to describe the ecology of phage-host systems: (1) the kill-the-winner model characterized by a boom-and-bust cycles between the phage and respective host abundances (Thingstad et al., 2008; Ogilvie and Jones, 2017); (2) the armsrace model referring to the co-evolution of phage and host, in which the bacterial host develops mechanisms to resist phage infection, which are continually countered by reciprocal adaptation of infecting phage (Thingstad, 2000; Hall et al., 2011); and (3) the fluctuating-selection model, where a balance in increase and decrease in populations is observed without eradication of phage or host, resulting in an established phage community and ensuring bacterial diversity (Mirzaei and Maurice, 2017). Although killthe-winner is suggested to be the dominant model in BWT (Shapiro et al., 2010; Brown et al., 2019), limited data on phage identity and abundance over time compromise the complete description of dynamics between phages and hosts (Rohwer and Thurber, 2009; Shapiro et al., 2010). In full-scale systems treating continuous and variable influent streams and subject to seasonal changes, the impact of phage infection might be mitigated by a more diverse and robust microbial culture, while also conditioned by operation and abiotic factors (Shade et al., 2012). It is likely that all models are observed in BWT, with kill-the-winner being suggested as dominant, but the population dynamics remain to be fully described. Literature offers speculations regarding the prevailing models in BWT, without, however, providing authoritative supporting evidence (Rodriguez-Brito et al., 2010; Brown et al., 2019). In addition, it is to note that prophage inducers, such as chemicals and stress conditions, are present by default in BWT systems (Muniesa et al., 2011) - but their efficiency as prophage inducers in a full-scale system was never explored.

\section{Opportunities and Potential Application of Phages in BWT}

Expanding research to investigate different BWT technologies and configurations is a chance to better understand the correlation between phages community, microbial community, and process. Consequently, it can yield crucial information to rethink the design and operation of BWT, and endorse biotechnological applications of phages. (Hatfull, 2008; Hayes et al., 2017).

High viral and microbial diversity of BWT constitute a valuable resource of useful - yet unknown - functional genes and organisms for biotechnological applications (Tamaki et al., 2012). Phage-mediated biocontrol, for example, for bulking and foam reduction, can be specific to the detrimental organisms and a more sustainable and low cost alternative to the use of chemical defoamers that are sometimes necessary in BWT tanks. Application of polyvalent phages can be useful as it can target multiple bacteria associated with an undesired 
phenomenon (Khairnar et al., 2014, 2016; Liu et al., 2015). Alternatively, a mixture of phages can target multiple detrimental bacteria or attach to different external receptors of the bacterial host (Oechslin, 2018). However, as mentioned in "Use of Specifically Isolated Phages for Bacterial Population Control," the application of phages as biocontrol agents in wastewater treatment processes has not been investigated at larger or full-scale systems. Besides the replication of the phage to high volumes and to an adequate concentration for an effective population control, the formulation of the bioagent needs to be considered to ensure phage activity and effectiveness (Malik et al., 2017). For instance, phages can be lyophilized and added as a powder if a change in volume could negatively impact treatment performance. Furthermore, when developing a phage-mediated biocontrol, it is necessary to consider the possible rapid development of phage-resistant mutants, which can ultimately deteriorate the phage application (Labrie et al., 2010; Oechslin, 2018). Besides the scope to further investigate and develop the examples provided in "Use of Specifically Isolated Phages for Bacterial Population Control" into feasible applications, it can be interesting to exploit phages that infect bacteria not related to foam or bulking phenomena, but to functional aspects, such as carbon conversion or nutrient removal.

Phage-mediated control can also be adapted as a microbial ecology tool to study the function of a key population in BWT. Applying phages to infect and decrease the abundance of functional bacteria and assessing how system performance changes can yield information about the role of the decimated bacteria (Haruta et al., 2009). This can be a valuable strategy to correlate structure and function of microbial communities and help disclose the paradigm of microbial ecology of linking bacteria identity to function. However, this perspective diverges from the main directions of current research on phages in BWT, usually focused on tracking pathogenic bacteria and pollution (Bayat et al., 2021; Ji et al., 2021).

Phages could also be used as monitoring tools and performance indicators. This is a similar approach to the use of phages as pathogens indicators (McMinn et al., 2018), but rather than being detected to assess pollution levels or decay of enteric viruses, they could be used as indications of key functional bacteria of BWT systems. The detection and identification of particular phages can provide information about the health and stability of the bacterial community and help predict disturbances based on population dynamics of phage-host systems (Aw et al., 2014; Stefanakis et al., 2019). Since phages are more resistant than, for instance, enteroviruses (Mocé-Llivina et al., 2003), and considering the estimation that they can persist for up to 30 days in the system (Tamaki et al., 2012), phages have the potential to be used as effluent quality indicators (Silverman et al., 2013; Yahya et al., 2015; Boehm, 2019). Further correlation of a phage ecogenomic fingerprint with treatment configuration and operation can evolve into a tool to monitor and control BWT in a quicker and more reliable way, again deviating from a health-related assessment toward a process and engineering perspective.

\section{Directions for Future Research}

Culture-based and -independent methods complement each other and should be carried out in parallel. Metagenomics and molecular methods, increasingly accessible, should be more widely explored and applied in BWT microbial ecology research. There is an opportunity to sequence all phages isolated from BWT systems, as only a few had their genome sequenced. Increasing data available in public repositories can mitigate the misrepresentation of the BWT virome in genome databases. New genetic sequences and respective annotations will continuously build a landscape of phages found in BWT, similar to existing metagenomic databases specific for viruses in fresh (Roux et al., 2012) and sea water (Hurwitz and Sullivan, 2013). Metagenomic data can also be used to investigate patterns or clusters of organisms that are concurrent and thus help correlate bacteria identity with a specific function in the system (Otawa et al., 2007; Ogilvie et al., 2018). Other culture-independent methods, such as proteomics and novel techniques to study phage-host range, can be applied to BWT viromes and yield additional information on activity and life cycle of phages. Future research should also focus on the development of new strategies to counter host specificity and development host cell resistance as these highly compromise the understanding of the interaction between phages and bacteria and potential biotechnological applications.

Efforts toward developing fundamental knowledge on identity, diversity, and phage-host infection dynamics will support and expand the application of phages for monitoring and control in BWT. All the reported examples of phages used as biological control agents are from lab-scale systems and most of them with highly enriched microbial communities. Future experiments should investigate the applicability of such phages to microbial communities of full-scale systems that generally have higher microbial diversity due to more complex composition and variability of the influent and operating conditions. Such approaches also help mitigate biases associated with lab-acclimatized systems and provide a more reliable hypothesis for phage-host dynamics in real, full-scale systems.

Time series studies in full-scale BWT systems can complement the investigations on the dynamics between the viral and bacterial populations on both full- and lab-scale systems. Such studies also provide data for a more in-depth analysis of the impact that influent, operation, and environmental conditions can have on phage abundance and activity. Thereby, continuous changes and microbial interactions that cannot always be mimicked in pure cultures or lab-scale reactors are considered. A more comprehensive sampling of full-scale BWT systems is also encouraged. It has been suggested that bacterial strains can migrate and disperse through different systems but need to adapt to the local bacteriophage population (Kunin et al., 2008). Sampling different stages of the treatment process or points of the treatment tank increase the chance of getting a representative landscape of phage population in BWT and can yield information about the fate and migration of phages in the system (Otawa et al., 2007). 
Another gap barely addressed is the functional influence of phages in BWT. Such impact can lead do a decrease in the abundance of useful microorganisms, impairing process performance, or be favorable to the microbial communities, or be favorable to the microbial communities, enhancing the resilience and stability of the culture or drive diversity and evolution. The effects of phage activity might be even more complex with different variations of life cycles taking place and constant co-evolution of phages and hosts. The virus-to-microbe ratio can be a good parameter to infer about lysogeny in the system, with low ratios usually being found in systems with high numbers of microbial cells and can indicate low propagation of phages and prevalence of lysogeny (Knowles et al., 2016). This parameter has not yet been explored for BWT systems. Statistical analysis and modeling of data collected from extensive sampling, over longer periods of time, can yield novel insights on the evolution of BWT viral and bacterial communities and the interactions shaping the structure and function of the system.

\section{CONCLUDING REMARKS}

Although phages are active members of microbial communities in BWT, very little is known about their identity and activity, with studies often overlooking their impact on treatment performance. The role of phages is a missing but integral piece for fully understanding microbial ecology of BWT but also to improve and monitor wastewater treatment and to design

\section{REFERENCES}

Ackermann, H. W. (2012). Bacteriophage electron microscopy. Adv. Virus Res. 82, 1-32. doi: 10.1016/B978-0-12-394621-8.00017-0

Adams, M. H. (1959). Bacteriophages New York, USA: Interscience Publishers. Alizon, S., and Van Baalen, M. (2008). Multiple infections, immune dynamics, and evolution of virulence. Am. Nat. 172, E150-E168. doi: 10.1086/590958

Angly, F. E., Felts, B., Breitbart, M., Salamon, P., Edwards, R. A., Carlson, C., et al. (2006). The marine viromes of four oceanic regions. PLoS Biol. 4:e368. doi: 10.1371/journal.pbio.0040368

Angly, F., Rodriguez-brito, B., Bangor, D., Mcnairnie, P., Breitbart, M., Salamon, P., et al. (2005). PHACCS, an online tool for estimating the structure and diversity of uncultured viral communities using metagenomic information. BMC Bioinformatics 6:41. doi: 10.1186/1471-2105-6-41

Aw, T. G., Howe, A., and Rose, J. B. (2014). Metagenomic approaches for direct and cell culture evaluation of the virological quality of wastewater. J. Virol. Methods 210, 15-21. doi: 10.1016/j.jviromet.2014.09.017

Barr, J. J., Slater, F. R., Fukushima, T., and Bond, P. L. (2010). Evidence for bacteriophage activity causing community and performance changes in a phosphorus-removal activated sludge. FEMS Microbiol. Ecol. 74, 631-642. doi: $10.1111 /$ j.1574-6941.2010.00967.x

Bayat, F., Didar, T. F., and Hosseinidoust, Z. (2021). Emerging investigator series: bacteriophages as nano engineering tools for quality monitoring and pathogen detection in water and wastewater. Environ. Sci. Nano 8, 367-389. doi: 10.1039/D0EN00962H

Becker, E. A., Burns, C. M., León, E. J., Rajabojan, S., Friedman, R., Friedrich, T. C., et al. (2012). Experimental analysis of sources of error in evolutionary studies based on Roche/454 pyrosequencing of viral genomes. Genome Biol. Evol. 4, 457-465. doi: 10.1093/gbe/evs029

Bengtsson, S., Blois, M.De, Wilén, B., and Gustavsson, D. (2018). Treatment of municipal wastewater with aerobic granular sludge. Crit. Rev. Environ. Sci. Technol. 48, 119-166. doi:10.1080/10643389.2018.1439653 innovative biotechnological solutions. This review provides routes for expanding the research of phages in BWT, including the most suitable methodologies and specific questions that need to be addressed. A deeper knowledge of phage ecology is a stepping stone in fully understanding the underlying microbial communities in BWT and is required to advance operation of full-scale systems.

\section{AUTHOR CONTRIBUTIONS}

The submitted review results from a project supervised by $\mathrm{AL}$ and $\mathrm{BJ}$. AL, VR, BJ, and SB conceptualized the structure and content of the manuscript. VR did the literature research and wrote the first draft of the manuscript. All authors reviewed the manuscript, provided comments, and complemented the reference list. BJ contributed more significantly to "Introduction" and "Methods to Study Phages in BWT Systems," while SB, JW, and AL to "Phages Identified in BWT Processes" and "Challenges and Opportunities for Studying Phages in BWT Systems." All authors contributed to the iterative revision and edition process and approved the submitted version.

\section{FUNDING}

This work was supported by the Engineering and Physical Sciences Research Council (grant number EP/L016354/1).

Bibby, K., Crank, K., Greaves, J., Li, X., Wu, Z., Hamza, I. A., et al. (2019) Metagenomics and the development of viral water quality tools. NPJ Clean Water 2, 1-13. doi: 10.1038/s41545-019-0032-3

Boehm, A. B. (2019). Risk-based water quality thresholds for coliphages in surface waters: Effect of temperature and contamination aging. Environ Sci Process Impacts 21, 2031-2041. doi: 10.1039/C9EM00376B

Bonilla, N., Rojas, M. I., Netto Flores Cruz, G., Hung, S.-H., Rohwer, F., and Barr, J. J. (2016). Phage on tap-protocol for the preparation of bacteriophage lab stocks. PeerJ 4:e2261. doi: 10.7717/peerj.2261

Bossi, L., Fuentes, J. A., Mora, G., and Figueroa-Bossi, N. (2003). Prophage Contribution to Bacterial Population Dynamics. J. Bacteriol. 185, 6467-6471. doi: 10.1128/JB.185.21.6467-6471.2003

Breitbart, M., Bonnain, C., Malki, K., and Sawaya, N. A. (2018). Phage puppet masters of the marine microbial realm. Nat. Microbiol. 3, 754-766. doi: 10.1038/s41564-018-0166-y

Breitbart, M., Haynes, M., Kelley, S., Angly, F., Edwards, R. A., Felts, B., et al. (2008). Viral diversity and dynamics in an infant gut. Res. Microbiol. 159, 367-373. doi: 10.1016/j.resmic.2008.04.006

Breitbart, M., Hewson, I., Felts, B., Mahaffy, J. M., Nulton, J., Salamon, P., et al. (2003). Metagenomic Analyses of an Uncultured Viral Community from Human Feces. J. Bacteriol. 185, 6220-6223. doi: 10.1128/ JB.185.20.6220-6223.2003

Brinkman, N. E., Villegas, E. N., Garland, J. L., and Keely, S. P. (2018). Reducing inherent biases introduced during DNA viral metagenome analyses of municipal wastewater. PLoS One 13:e0195350. doi: 10.1371/journal. pone.0195350

Brown, M. R., Baptista, J. C., Lunn, M., Swan, D. L., Smith, S. J., Davenport, R. J., et al. (2019). Coupled virus-bacteria interactions and ecosystem function in an engineered microbial system. Water Res. 152, 264-273. doi: 10.1016/j. watres.2019.01.003

Brown, M. R., Camézuli, S., Davenport, R. J., Petelenz-Kurdziel, E., Øvreås, L., and Curtis, T. P. (2015). Flow cytometric quantification of viruses in activated sludge. Water Res. 68, 414-422. doi: 10.1016/j.watres.2014.10.018 
Brum, J. R., and Sullivan, M. B. (2015). Rising to the challenge: accelerated pace of discovery transforms marine virology. Nat. Rev. Microbiol. 13, 147-159. doi: 10.1038/nrmicro3404

Calero-Cáceres, W., Ye, M., and Balcázar, J. L. (2019). Bacteriophages as Environmental Reservoirs of Antibiotic Resistance. Trends Microbiol. 27, 570-577. doi: 10.1016/j.tim.2019.02.008

Choi, J., Kotay, S. M., and Goel, R. (2010). Various physico-chemical stress factors cause prophage induction in Nitrosospira multiformis 25196- an ammonia oxidizing bacteria. Water Res. 44, 4550-4558. doi: 10.1016/j.watres.2010.04.040

Clokie, M. R. J., and Kropinski, A. M. (2009) in Bacteriophages - Methods and Protocols. ed. J. M. Walker (Leicester, UK: Humana Press), 69-76.

Clokie, M. R. J., Millard, A. D., Letarov, A. V., and Heaphy, S. (2011). Phages in nature. Bacteriophage 1, 31-45. doi: 10.4161/bact.1.1.14942

Culligan, E. P., Sleator, R. D., Marchesi, J. R., and Hill, C. (2014). Metagenomics and novel gene discovery: Promise and potential for novel therapeutics. Virulence 5, 399-412. doi: 10.4161/viru.27208

Dang, V. T., and Sullivan, M. B. (2014). Emerging methods to study bacteriophage infection at the single-cell level. Front. Microbiol. 5:724. doi: 10.3389/ fmicb.2014.00724

Danovaro, R., Dell'Anno, A., Trucco, A., Serresi, M., and Vanucci, S. (2001). Determination of Virus Abundance in Marine Sediments. Appl. Environ. Microbiol. 67, 1384-1387. doi: 10.1128/AEM.67.3.1384-1387.2001

Diard, M., and Hardt, W.-D. (2017). Evolution of bacterial virulence. FEMS Microbiol. Rev. 41, 679-697. doi: 10.1093/femsre/fux023

Dias, F. F., and Bhat, J. V. (1965). Microbial Ecology of Activated Sludge. Appl. Microbiol. 13, 257-261. doi: 10.1128/am.13.2.257-261.1965

Duerkop, B. A., Clements, C. V., Rollins, D., Rodrigues, J. L. M., and Hooper, L. V. (2012). A composite bacteriophage alters colonization by an intestinal commensal bacterium. Proc. Natl. Acad. Sci. U. S. A. 109, 17621-17626. doi: 10.1073/pnas.1206136109

Ewert, D. L., and Paynter, M. J. B. (1980). Enumeration of Bacteriophages and Host Bacteria in Sewage and the Activated-Sludge Treatment Process. Appl. Environ. Microbiol. 39, 576-583. doi: 10.1128/aem.39.3.576-583.1980

Fan, N., Qi, R., and Yang, M. (2017). Isolation and characterization of a virulent bacteriophage infecting Acinetobacter johnsonii from activated sludge. Res. Microbiol. 168, 472-481. doi: 10.1016/j.resmic.2017.01.006

Fan, N., Yang, M., Jin, R., and Qi, R. (2019). Isolation and Genomic Characterization of an Acinetobacter johnsonii Bacteriophage AJO2 From Bulking Activated Sludge Bacterial Strains and Culture Conditions. Front. Microbiol. 10:266. doi: $10.3389 /$ fmicb.2019.00266

Farkas, K., Walker, D. I., Adriaenssens, E. M., McDonald, J. E., Hillary, L. S., Malham, S. K., et al. (2020). Viral indicators for tracking domestic wastewater contamination in the aquatic environment. Water Res. 181:115926. doi: $10.1016 /$ j.watres.2020.115926

Filippini, M., and Middelboe, M. (2007). Viral abundance and genome size distribution in the sediment and water column of marine and freshwater ecosystems. FEMS Microbiol. Ecol. 60, 397-410. doi: 10.1111/j.1574-6941.2007.00298.x

Flannery, J., Keaveney, S., Rajko-Nenow, P., O’Flaherty, V., and Doré, W. (2013). Norovirus and FRNA bacteriophage determined by RT-qPCR and infectious FRNA bacteriophage in wastewater and oysters. Water Res. 47, 5222-5231. doi: 10.1016/j.watres.2013.06.008

Fong, T.-T., and Lipp, E. K. (2005). Enteric Viruses of Humans and Animals in Aquatic Environments: Health Risks, Detection, and Potential Water Quality Assessment Tools. Microbiol. Mol. Biol. Rev. 69, 357-371. doi: 10.1128/ MMBR.69.2.357-371.2005

Fortier, L., and Sekulovic, O. (2013). Importance of prophages to evolution and virulence of bacterial pathogens. Virulence 4, 354-365. doi: 10.4161/viru.24498

Gilbert, J. A., and Dupont, C. L. (2011). Microbial Metagenomics: Beyond the Genome. Аnnu. Rev. Mar. Sci. 3, 347-371. doi: 10.1146/annurevmarine-120709-142811

Girones, R., Ferrús, M. A., Alonso, J. L., Rodriguez-Manzano, J., Calgua, B., de Abreu Corrêa, A., et al. (2010). Molecular detection of pathogens in water - The pros and cons of molecular techniques. Water Res. 44, 4325-4339. doi: 10.1016/j.watres.2010.06.030

Green, M. R., and Sambrook, J. (2012). Molecular Cloning - A Laboratory Manual. 4th Edn. John Inglis.

Hall, A. R., Scanlan, P. D., Morgan, A. D., and Buckling, A. (2011). Hostparasite coevolutionary arms races give way to fluctuating selection. Ecol. Lett. 14, 635-642. doi: 10.1111/j.1461-0248.2011.01624.x
Handelsman, J. (2004). Metagenomics: Application of Genomics to Uncultured Microorganisms. Microbiol. Mol. Biol. Rev. 68, 669-685. doi: 10.1128/ MMBR.68.4.669-685.2004

Hantula, J., Kurki, A., Vuoriranta, P., and Bamford, D. H. (1991). Ecology of Bacteriophages Infecting Activated Sludge Bacteria. Appl. Environ. Microbiol. 57, 2147-2151. doi: 10.1128/aem.57.8.2147-2151.1991

Haruta, S., Kato, S., Yamamoto, K., and Igarashi, Y. (2009). Intertwined interspecies relationships: approaches to untangle the microbial network. Environ. Microbiol. 11, 2963-2969. doi: 10.1111/j.1462-2920.2009.01956.x

Hatfull, G. F. (2008). Bacteriophage Genomics. Curr. Opin. Microbiol. 11, 447-453. doi: 10.1016/j.mib.2008.09.004

Hatfull, G. F., and Hendrix, R. W. (2011). Bacteriophages and their genomes. Curr. Opin. Virol. 1, 298-303. doi: 10.1016/j.coviro.2011.06.009

Hayes, S., Mahony, J., Nauta, A., and Sinderen, D.Van (2017). Metagenomic Approaches to Assess Bacteriophages in Various Environmental Niches. Viruses 9:127. doi:10.3390/v9060127

Henze, M., van Loosdrecht, M. C. M., Ekama, G. A., and Brdjanovic, D. (2008). Biological Wastewater Treatment: Principles, Modelling and Design. London, UK: IWA publishing.

Heyer, R., Schallert, K., Siewert, C., Kohrs, F., Greve, J., Maus, I., et al. (2019). Metaproteome analysis reveals that syntrophy, competition, and phage-host interaction shape microbial communities in biogas plants. Microbiome 7:69. doi: 10.1186/s40168-019-0673-y

Holt, J. G., Krieg, N. R., Sneath, P. H. A., Staley, J. T., and Williams, S. T. (1994). Bergey's Manual of Determinative Bacteriology. 9th Edn. London: Williams \& Wilkins.

Howard-Varona, C., Hargreaves, K. R., Abedon, S. T., and Sullivan, M. B. (2017). Lysogeny in nature: mechanisms, impact and ecology of temperate phages. ISME J. 11, 1511-1520. doi: 10.1038/ismej.2017.16

Hoyles, L., McCartney, A. L., Neve, H., Gibson, G. R., Sanderson, J. D., Heller, K. J., et al. (2014). Characterization of virus-like particles associated with the human faecal and caecal microbiota. Res. Microbiol. 165, 803-812. doi: $10.1016 /$ j.resmic.2014.10.006

Hurwitz, B. L., and Sullivan, M. B. (2013). The Pacific Ocean virome (POV): a marine viral metagenomic dataset and associated protein clusters for quantitative viral ecology. PLoS One 8:e57355. doi: 10.1371/journal. pone. 0057355

Hyman, P. (2019). Phages for phage therapy: Isolation, characterization, and host range breadth. Pharmaceuticals 12:35. doi: 10.3390/ph12010035

Iker, B. C., Bright, K. R., Pepper, I. L., Gerba, C. P., and Kitajima, M. (2013). Evaluation of commercial kits for the extraction and purification of viral nucleic acids from environmental and fecal samples. J. Virol. Methods 191, 24-30. doi: 10.1016/j.jviromet.2013.03.011

Imamovic, L., Ballesté, E., Jofre, J., and Muniesa, M. (2010). Quantification of Shiga toxin-converting bacteriophages in wastewater and in fecal samples by real-time quantitative PCR. Appl. Environ. Microbiol. 76, 5693-5701. doi: 10.1128/AEM.00107-10

Iyer, L. M., Anantharaman, V., Krishnan, A., Maxwell Burroughs, A., and Aravind, L. (2021). Jumbo phages: a comparative genomic overview of core functions and adaptions for biological conflicts. Viruses 13:63. doi: 10.3390/v13010063

Jakociune, D., and Moodley, A. (2018). A Rapid Bacteriophage DNA Extraction Method. Methods Protoc. 1:27. doi: 10.3390/mps1030027

Ji, M., Liu, Z., Sun, K., Li, Z., Fan, X., and Li, Q. (2021). Bacteriophages in water pollution control: advantages and limitations. Front. Environ. Sci. Eng. 15:84. doi: 10.1007/s11783-020-1378-y

Jo, S. J., Kwon, H., Jeong, S. Y., Lee, C. H., and Kim, T. G. (2016). Comparison of microbial communities of activated sludge and membrane biofilm in 10 full-scale membrane bioreactors. Water Res. 101, 214-225. doi: 10.1016/j. watres.2016.05.042

Jofre, J., Blanch, A. R., Lucena, F., and Muniesa, M. (2014). Bacteriophages infecting Bacteroides as a marker for microbial source tracking. Water Res. 55, 1-11. doi: 10.1016/j.watres.2014.02.006

Katayama, H., Shimasaki, A., and Ohgaki, S. (2002). Development of a virus concentration method and its application to detection of enterovirus and Norwalk virus from coastal seawater. Appl. Environ. Microbiol. 68, 1033-1039. doi: 10.1128/AEM.68.3.1033-1039.2002

Kelleher, P., Murphy, J., Mahony, J., and van Sinderen, D. (2015). Next-generation sequencing as an approach to dairy starter selection. Dairy Sci. Technol. 95, 545-568. doi: 10.1007/s13594-015-0227-4 
Ketratanakul, A., and Ohgaki, S. (1989). Indigenous coliphages and RNA-FSpecific coliphages associated with suspended solids in the activated sludge process. Water Sci. Technol. 21, 73-78. doi: 10.2166/wst.1989.0081

Khairnar, K., Chandekar, R., Nair, A., Pal, P., and Paunikar, W. N. (2016). Novel application of bacteriophage for controlling foaming in wastewater treatment plant- an eco-friendly approach. Bioengineered 7, 46-49. doi: 10.1080/21655979.2015.1134066

Khairnar, K., Pal, P., Chandekar, R. H., and Paunikar, W. N. (2014). Isolation and Characterization of Bacteriophages Infecting Nocardioforms in Wastewater Treatment Plant. Biotechnol. Res. Int. 2014:151952. doi: 10.1155/2014/151952

Khan, M. A., Satoh, H., Katayama, H., Kurisu, F., and Mino, T. (2002a). Bacteriophages isolated from activated sludge processes and their polyvalency. Water Res. 36, 3364-3370. doi: 10.1016/s0043-1354(02)00029-5

Khan, M. A., Satoh, H., Mino, T., Katayama, H., Kurisu, F., and Matsuo, T. (2002b). Bacteriophage-host interaction in the enhanced biological phosphate removing activated sludge system. Water Sci. Technol. 46, 39-43. doi: 10.2166/ wst.2002.0453

Kim, J., Lim, J., and Lee, C. (2013a). Quantitative real-time PCR approaches for microbial community studies in wastewater treatment systems: Applications and considerations. Biotechnol. Adv. 31, 1358-1373. doi: 10.1016/j. biotechadv.2013.05.010

Kim, M. S., Park, E. J., Roh, S. W., and Bae, J. W. (2011). Diversity and abundance of single-stranded DNA viruses in human feces. Appl. Environ. Microbiol. 77, 8062-8070. doi: 10.1128/AEM.06331-11

Kim, M.-S., Whon, T. W., and Bae, J.-W. (2013b). Comparative Viral Metagenomics of Environmental Samples from Korea. Genomics Inform. 11:121. doi: 10.5808/ gi.2013.11.3.121

Kitajima, M., Iker, B. C., Pepper, I. L., and Gerba, C. P. (2014). Relative abundance and treatment reduction of viruses during wastewater treatment processes - Identification of potential viral indicators. Sci. Total Environ. 488-489, 290-296. doi: 10.1016/j.scitotenv.2014.04.087

Kivelä, H. M., Kalkkinen, N., and Bamford, D. H. (2002). Bacteriophage PM2 Has a Protein Capsid Surrounding a Spherical Proteinaceous Lipid Core. J. Virol. 76, 8169-8178. doi: 10.1128/JVI.76.16.8169-8178.2002

Kleiner, M., Hooper, L. V., and Duerkop, B. A. (2015). Evaluation of methods to purify virus-like particles for metagenomic sequencing of intestinal viromes. BMC Genomics 16:7. doi: 10.1186/s12864-014-1207-4

Knowles, B., Silveira, C. B., Bailey, B. A., Barott, K., Cantu, V. A., Cobian-Guëmes, A. G., et al. (2016). Lytic to temperate switching of viral communities. Nature 531, 466-470. doi: 10.1038/nature17193

Koskella, B., and Brockhurst, M. A. (2014). Bacteria-phage coevolution as a driver of ecological and evolutionary processes in microbial communities. FEMS Microbiol. Rev., 916-931. doi: 10.1111/1574-6976.12072

Koskella, B., and Meaden, S. (2013). Understanding bacteriophage specificity in natural microbial communities. Viruses 5, 806-823. doi: 10.3390/v5030806

Kotay, S. M., Datta, T., Choi, J., and Goel, R. (2011). Biocontrol of biomass bulking caused by Haliscomenobacter hydrossis using a newly isolated lytic bacteriophage. Water Res. 45, 694-704. doi: 10.1016/j.watres.2010.08.038

Kunin, V., He, S., Warnecke, F., Peterson, S. B., Garcia Martin, H., Haynes, M., et al. (2008). A bacterial metapopulation adapts locally to phage predation despite global dispersal. Genome Res. 18, 293-297. doi: 10.1101/gr.6835308

Labrie, S. J., Samson, J. E., and Moineau, S. (2010). Bacteriophage resistance mechanisms. Nat. Rev. Microbiol. 8, 317-327. doi: 10.1038/nrmicro2315

Lawrence, D., Baldridge, M. T., and Handley, S. A. (2019). Phages and human health: More than idle hitchhikers. Viruses 11:587. doi: 10.3390/v11070587

Lee, S. H., Onuki, M., Satoh, H., and Mino, T. (2006). Isolation, characterization of bacteriophages specific to Microlunatus phosphovorus and their application for rapid host detection. Lett. Appl. Microbiol. 42, 259-264. doi: 10.1111/j. 1472-765X.2006.01840.x

Lee, S. H., Otawa, K., Onuki, M., Satoh, H., and Mino, T. (2007). Population dynamics of phage-host system of Microlunatus phosphovorus indigenous in activated sludge. J. Microbiol. Biotechnol. 17, 1704-1707.

Lee, S. H., Satoh, H., Katayama, H., and Mino, T. (2004). Isolation, physiological characterization of bacteriophages from enhanced biological phosphorous removal activated sludge and their putative role. J. Microbiol. Biotechnol. $14,730-736$.

Leplae, R., Lima-mendez, G., and Toussaint, A. (2010). ACLAME: A CLAssification of Mobile genetic Elements, update 2010. Nucleic Acids Res. 38, D57-D61. doi: $10.1093 /$ nar/gkp938
Lima-Mendez, G., Toussaint, A., and Leplae, R. (2007). Analysis of the phage sequence space: The benefit of structured information. Virology 365, 241-249. doi: 10.1016/j.virol.2007.03.047

Lin, D. M., Koskella, B., and Lin, H. C. (2017). Phage therapy: An alternative to antibiotics in the age of multi-drug resistance. World J. Gastrointest. Pharmacol. Ther. 8:162. doi: 10.4292/wjgpt.v8.i3.162

Liu, M., Gill, J. J., Young, R., and Summer, E. J. (2015). Bacteriophages of wastewater foaming-associated filamentous Gordonia reduce host levels in raw activated sludge. Sci. Rep. 5:13754. doi: 10.1038/srep13754

Logan, K. B., Rees, G. E., Seeley, N. D., and Primrose, S. B. (1980). Rapid concentration of bacteriophages from large volumes of freshwater: Evaluation of positively charged, microporous filters. J. Virol. Methods 1, 87-97. doi: 10.1016/0166-0934(80)90017-8

Lundstrom, K. H., Bamford, D. H., Palva, E. T., and Lounatmaa, K. (1979). Lipid-containing bacteriophage PR4: Structure and life cycle. J. Gen. Virol. 43, 583-592. doi: 10.1099/0022-1317-43-3-583

Malik, D. J., Sokolov, I. J., Vinner, G. K., Mancuso, F., Cinquerrui, S., Vladisavljevic, G. T., et al. (2017). Formulation, stabilisation and encapsulation of bacteriophage for phage therapy. Adv. Colloid Interf. Sci. 249, 100-133. doi: $10.1016 /$ j.cis.2017.05.014

Marine, R. L., Magaña, L. C., Castro, C. J., Zhao, K., Montmayeur, A. M., Schmidt, A., et al. (2020). Comparison of Illumina MiSeq and the Ion Torrent PGM and S5 platforms for whole-genome sequencing of picornaviruses and caliciviruses. J. Virol. Methods 280:113865. doi: 10.1016/j. jviromet.2020.113865

Maslov, S., and Sneppen, K. (2017). Population cycles and species diversity in dynamic Kill-the-Winner model of microbial ecosystems. Sci. Rep. 7:39642. doi: $10.1038 /$ srep39642

McMinn, B. R., Ashbolt, N. J., and Korajkic, A. (2018). Bacteriophages as indicators of fecal pollution and enteric virus removal. Lett. Appl. Microbiol. 65, 11-26. doi: 10.1111/lam.12736.Submit

Mirzaei, M. K., and Maurice, C. F. (2017). Ménage à trois in the human gut: interactions between host, bacteria and phages. Nat. Publ. Gr. 15, 397-408. doi: 10.1038/nrmicro.2017.30

Mizuno, C. M., Rodriguez-valera, F., Kimes, N. E., and Ghai, R. (2013). Expanding the Marine Virosphere Using Metagenomics. PLoS Genet. 9:e1003987. doi: 10.1371/journal.pgen.1003987

Mocé-Llivina, L., Muniesa, M., Pimenta-Vale, H., Lucena, F., and Jofre, J. (2003). Survival of bacterial indicator species and bacteriophages after thermal treatment of sludge and sewage. Appl. Environ. Microbiol. 69, 1452-1456. doi: 10.1128/AEM.69.3.1452-1456.2003

Mohiuddin, M., and Schellhorn, H. E. (2015). Spatial and temporal dynamics of virus occurrence in two freshwater lakes captured through metagenomic analysis. Front. Microbiol. 6:960. doi: 10.3389/fmicb.2015.00960

Monpoeho, S., Maul, A., Mignotte-Cadiergues, B., Schwartzbrod, L., Billaudel, S., and Ferré, V. (2001). Best Viral Elution Method Available for Quantification of Enteroviruses in Sludge by Both Cell Culture and Reverse TranscriptionPCR. Appl. Environ. Microbiol. 67, 2484-2488. doi: 10.1128/ AEM.67.6.2484-2488.2001

Monteiro, R., Pires, D. P., Costa, A. R., and Azeredo, J. (2019). Phage Therapy: Going Temperate? Trends Microbiol. 27, 368-378. doi: 10.1016/j.tim.2018.10.008

Motlagh, A. M., Bhattacharjee, A. S., and Goel, R. (2015). Microbiological study of bacteriophage induction in the presence of chemical stress factors in enhanced biological phosphorus removal (EBPR). Water Res. 81, 1-14. doi: $10.1016 /$ j.watres.2015.04.023

Muniesa, M., Imamovic, L., and Jofre, J. (2011). Bacteriophages and genetic mobilization in sewage and faecally polluted environments. Microb. Biotechnol. 4, 725-734. doi: 10.1111/j.1751-7915.2011.00264.x

Nakai, T., and Park, S. C. (2002). Bacteriophage therapy of infectious diseases in aquaculture. Res. Microbiol. 153, 13-18. doi: 10.1016/S0923-2508(01)01280-3

Nielsen, P. H., Mcilroy, S. J., and Albertsen, M. (2019). Re-evaluating the microbiology of the enhanced biological phosphorus removal process. Curr. Opin. Biotechnol. 57, 111-118. doi: 10.1016/j.copbio.2019.03.008

Oechslin, F. (2018). Resistance development to bacteriophages occurring during bacteriophage therapy. Viruses 10:351. doi: 10.3390/v10070351

Ogata, S., Miyamoto, H., and Hayashida, S. (1980). An investigation of the influence of bacteriophages on the bacterial flora and purification powers of activated sludge. J. Gen. Appl. Microbiol. 108, 97-108. doi: 10.2323/ jgam.26.97 
Ogilvie, L. A., and Jones, B. V. (2015). The human gut virome: A multifaceted majority. Front. Microbiol. 6:918. doi: 10.3389/fmicb.2015.00918

Ogilvie, L. A., and Jones, B. V. (2017). The human gut virome: form and function. Emerg. Top. Life Sci. 1, 351-362. doi: 10.1042/ETLS20170039

Ogilvie, L. A., Nzakizwanayo, J., Guppy, F. M., and Ebdon, J., and Jones, B. V (2018). Resolution of habitat-associated ecogenomic signatures in bacteriophage genomes and application to microbial source tracking. ISME J. 12, 942-958. doi:10.1038/s41396-017-0015-7

Otawa, K., Lee, S. H., Yamazoe, A., Onuki, M., Satoh, H., and Mino, T. (2007). Abundance, diversity, and dynamics of viruses on microorganisms in activated sludge processes. Microb. Ecol. 53, 143-152. doi: 10.1007/s00248-006-9150-9

Palermo, C. N., Fulthorpe, R. R., Saati, R., and Short, S. M. (2019). Metagenomic Analysis of Virus Diversity and Relative Abundance in a Eutrophic Freshwater Harbour. Viruses 11:792. doi: 10.3390/v11090792

Pan, D., Nolan, J., Williams, K. H., Robbins, M. J., Weber, K. A., and Weber, K. A. (2017). Abundance and Distribution of Microbial Cells and Viruses in an Alluvial Aquifer. Front. Environ. Sci. 8:1199. doi: 10.3389/fmicb.2017.01199

Parsley, L. C., Consuegra, E. J., Thomas, S. J., Bhavsar, J., Land, A. M., Bhuiyan, N. N., et al. (2010). Census of the viral metagenome within an activated sludge microbial assemblage. Appl. Environ. Microbiol. 76, 2673-2677. doi: 10.1128/AEM.02520-09

Patel, A., Noble, R. T., Steele, J. A., Schwalbach, M. S., Hewson, I., and Fuhrman, J. A. (2007). Virus and prokaryote enumeration from planktonic aquatic environments by epifluorescence microscopy with SYBR Green I. Nat. Protoc. 2, 269-276. doi: 10.1038/nprot.2007.6

Payan, A., Ebdon, J., Taylor, H., Gantzer, C., Ottoson, J., Papageorgiou, G. T., et al. (2005). Method for Isolation of Bacteroides Bacteriophage Host Strains Suitable for Tracking Sources of Fecal Pollution in Water. Appl. Environ. Microbiol. 71, 5659-5662. doi: 10.1128/AEM.71.9.5659-5662.2005

Pérez-Losada, M., Arenas, M., Galán, J. C., and Bracho, M. A. (2020). Infection, Genetics and Evolution High-throughput sequencing (HTS) for the analysis of viral populations. Infect. Genet. Evol. 80:104208. doi: 10.1016/j.meegid.2020.104208

Petrovich, M. L., Ben Maamar, S., Hartmann, E. M., Murphy, B. T., Poretsky, R. S., and Wells, G. F. (2019). Viral composition and context in metagenomes from biofilm and suspended growth municipal wastewater treatment plants. Microb. Biotechnol. 12, 1324-1336. doi: 10.1111/1751-7915.13464

Petrovski, S., Dyson, Z. A., Seviour, R. J., and Tillett, D. (2012). Small but Sufficient: the Rhodococcus Phage RRH1 Has the Smallest Known Siphoviridae Genome at 14.2 Kilobases. J. Virol. 86, 358-363. doi: 10.1128/jvi.05460-11

Petrovski, S., Seviour, R. J., and Tillett, D. (2011a). Characterization of the genome of the polyvalent lytic bacteriophage GTE2, which has potential for biocontrol of Gordonia-, Rhodococcus-, and Nocardia-stabilized foams in activated sludge plants. Appl. Environ. Microbiol. 77, 3923-3929. doi: 10.1128/AEM.00025-11

Petrovski, S., Seviour, R. J., and Tillett, D. (2011b). Genome sequence and characterization of the Tsukamurella bacteriophage TPA2. Appl. Environ. Microbiol. 77, 1389-1398. doi: 10.1128/AEM.01938-10

Petrovski, S., Seviour, R. J., and Tillett, D. (2011c). Prevention of Gordonia and Nocardia stabilized foam formation by using bacteriophage GTE7. Appl. Environ. Microbiol. 77, 7864-7867. doi: 10.1128/AEM.05692-11

Petrovski, S., Seviour, R. J., and Tillett, D. (2013). Characterization and whole genome sequences of the Rhodococcus bacteriophages RGL3 and RER2. Arch. Virol. 158, 601-609. doi: 10.1007/s00705-012-1530-5

Petrovski, S., Seviour, R. J., and Tillett, D. (2014). Genome sequence of the Nocardia bacteriophage NBR1. Arch. Virol. 159, 167-173. doi: 10.1007/ s00705-013-1799-z

Pollard, P. C. (2012). Enumerating viruses by using fluorescence and the nature of the nonviral background fraction. Appl. Environ. Microbiol. 78, 6615-6618. doi: 10.1128/AEM.01268-12

Poullain, V., Gandon, S., Brockhurst, M. A., Buckling, A., and Hochberg, M. E. (2008). The evolution of specificity in evolving and coevolving antagonistic interactions between a bacteria and its phage. Evolution 62, 1-11. doi: 10.1111/j.1558-5646.2007.00260.x

Pratama, A. A., and van Elsas, J. D. (2018). The 'Neglected' Soil Virome Potential Role and Impact. Trends Microbiol. 26, 649-662. doi: 10.1016/j. tim.2017.12.004

Principi, N., Silvestri, E., and Esposito, S. (2019). Advantages and limitations of bacteriophages for the treatment of bacterial infections. Front. Pharmacol. 10:513. doi: $10.3389 /$ fphar.2019.00513
Reyes, A., Haynes, M., Hanson, N., Angly, F. E., Heath, A. C., Rohwer, F., et al. (2010). Viruses in the faecal microbiota of monozygotic twins and their mothers. Nature 466, 334-338. doi: 10.1038/nature09199

Reyes, A., Semenkovich, N. P., Whiteson, K., Rohwer, F., and Gordon, J. I. (2013a). Going viral: next generation sequencing applied to human gut phage populations. Nat. Rev. Microbiol. 10, 607-617. doi: 10.1038/nrmicro2853.Going

Reyes, A., Wu, M., Mcnulty, N. P., Rohwer, F. L., and Gordon, J. I. (2013b). Gnotobiotic mouse model of phage - bacterial host dynamics in the human gut. Proc. Natl. Acad. Sci. U. S. A. 110, 20236-20241. doi: 10.1073/ pnas. 1319470110

Richert-Pöggeler, K. R., Franzke, K., Hipp, K., and Kleespies, R. G. (2019). Electron microscopy methods for virus diagnosis and high resolution analysis of viruses. Front. Microbiol. 9:3255. doi: 10.3389/fmicb.2018.03255

Rihtman, B., Meaden, S., Clokie, M. R. J., Koskella, B., and Millard, A. D. (2016). Assessing Illumina technology for the high-throughput sequencing of bacteriophage genomes. PeerJ 4:e2055. doi: 10.7717/peerj.2055

Rinke, C., Schwientek, P., Sczyrba, A., Ivanova, N. N., Anderson, I. J., Cheng, J., et al. (2013). Insights into the phylogeny and coding potential of microbial dark matter. Nature 499, 431-437. doi: 10.1038/nature12352

Rodriguez-Brito, B., Li, L. L., Wegley, L., Furlan, M., Angly, F., Breitbart, M., et al. (2010). Viral and microbial community dynamics in four aquatic environments. ISME J. 4, 739-751. doi: 10.1038/ismej.2010.1

Rohwer, F., and Thurber, R. V. (2009). Viruses manipulate the marine environment. Nature 459, 207-212. doi: 10.1038/nature08060

Ross, A., Ward, S., and Hyman, P. (2016). More is better: selecting for broad host range bacteriophages. Front. Microbiol. 7:1352. doi: 10.3389/ fmicb.2016.01352

Roux, S., Enault, F., Robin, A., Ravet, V., Sebastien Personnic, S. T., Colombet, J., et al. (2012). Assessing the diversity and specificity of two freshwater viral communities through metagenomics. PLoS One 7:e33641. doi: 10.1371/journal. pone.0033641

Roux, S., Krupovic, M., Debroas, D., Forterre, P., and Enault, F. (2013). Assessment of viral community functional potential from viral metagenomes may be hampered by contamination with cellular sequences. Open Biol. 3:130160. doi: 10.1098/rsob.130160

Russell, D. A., and Hatfull, G. F. (2017). PhagesDB: the actinobacteriophage database. Bioinformatics 33, 784-786. doi: 10.1093/bioinformatics/btw711

Sadeghi, G., Schijven, J. F., Behrends, T., Hassanizadeh, S. M., Gerritse, J., and Kleingeld, P. J. (2011). Systematic Study of Effects of $\mathrm{pH}$ and Ionic Strength on Attachment of Phage PRD1. Ground Water 49, 12-19. doi: 10.1111/j.1745-6584.2010.00767.x

Salisbury, A., and Tsourkas, P. K. (2019). A method for improving the accuracy and efficiency of bacteriophage genome annotation. Int. J. Mol. Sci. 20. doi: $10.3390 /$ ijms 20143391

Shade, A., Peter, H., Allison, S. D., Baho, D. L., Berga, M., Bürgmann, H., et al. (2012). Fundamentals of microbial community resistance and resilience. Front. Microbiol. 3:417. doi: 10.3389/fmicb.2012.00417

Shahin, K., Bao, H., Komijani, M., Barazandeh, M., Bouzari, M., Hedayatkhah, A., et al. (2019). Isolation, characterization, and PCR-based molecular identification of a siphoviridae phage infecting Shigella dysenteriae. Microb. Pathog. 131, 175-180. doi: 10.1016/j.micpath.2019.03.037

Shapiro, O. H., Kushmaro, A., and Brenner, A. (2010). Bacteriophage predation regulates microbial abundance and diversity in a full-scale bioreactor treating industrial wastewater. ISME J. 4, 327-336. doi: 10.1038/ismej.2009.118

Sharma, S., Chatterjee, S., Datta, S., Prasad, R., Dubey, D., Prasad, R. K., et al. (2017). Bacteriophages and its applications: an overview. Folia Microbiol. 62, 17-55. doi: 10.1007/s12223-016-0471-x

Sharp, R. (2001). Bacteriophages: Biology and history. J. Chem. Technol. Biotechnol. 76, 667-672. doi: 10.1002/jctb.434

Shibata, A., Goto, Y., Saito, H., Kikuchi, T., Toda, T., and Taguchi, S. (2006). Comparison of SYBR Green I and SYBR Gold stains for enumerating bacteria and viruses by epifluorescence microscopy. Aquat. Microb. Ecol. 43, 223-231. doi: 10.3354/ame043223

Silverman, A. I., Peterson, B. M., Boehm, A. B., McNeill, K., and Nelson, K. L. (2013). Sunlight inactivation of human viruses and bacteriophages in coastal waters containing natural photosensitizers. Environ. Sci. Technol. 47, 1870-1878. doi: 10.1021/es3036913

Simmons, E. L., Bond, M. C., Koskella, B., Drescher, K., Bucci, V., and Nadell, C. D. (2020). Biofilm Structure Promotes Coexistence of Phage- 
Resistant and Phage-Susceptible Bacteria. AIMS Microbiol. 5:e00877-19. doi: 10.1128 /mSystems.00877-19

Solonenko, S. A., and Sullivan, M. B. (2013). Preparation of metagenomic libraries from naturally occurring marine viruses. Methods Enzymol. 531, 143-165. doi: 10.1016/B978-0-12-407863-5.00008-3

Stefanakis, A. I., Bardiau, M., Trajano, D., Couceiro, F., Williams, J. B., and Taylor, H. (2019). Presence of bacteria and bacteriophages in full-scale trickling filters and an aerated constructed wetland. Sci. Total Environ. 659, 1135-1145. doi: 10.1016/j.scitotenv.2018.12.415

Sullivan, M. B., Waterbury, J. B., and Chisholm, S. W. (2003). Cyanophages infecting the oceanic cyanobacterium Prochlorococcus. Nature 424, 1047-1051. doi: $10.1038 /$ nature 02147

Suttle, C. A. (2007). Marine viruses - major players in the global ecosystem. Nat. Rev. 5, 801-812. doi: 10.1038/nrmicro1750

Suttle, C. A., Chan, A. M., and Cottrell, M. T. (1991). Use of ultrafiltration to isolate viruses from seawater which are pathogens of marine phytoplankton. Appl. Environ. Microbiol. 57, 721-726. doi: 10.1128/ aem.57.3.721-726.1991

Svircev, A., Roach, D., and Castle, A. (2018). Framing the future with bacteriophages in agriculture. Viruses 10:218. doi: 10.3390/v10050218

Tamaki, H., Zhang, R., Angly, F. E., Nakamura, S., Hong, P. Y., Yasunaga, T., et al. (2012). Metagenomic analysis of DNA viruses in a wastewater treatment plant in tropical climate. Environ. Microbiol. 14, 441-452. doi: $10.1111 / \mathrm{j} .1462-2920.2011 .02630 . x$

Thingstad, T. F. (2000). Elements of a theory for the mechanisms controlling abundance, diversity, and biogeochemical role of lytic bacterial viruses in aquatic systems. Limnol. Oceanogr. 45, 1320-1328. doi: 10.4319/ lo.2000.45.6.1320

Thingstad, T. F., Bratbak, G., and Heldal, M. (2008). "Aquatic phage ecology," in Bacteriophage Ecology: Population Growth, Evolution, and Impact of Bacterial Viruses. ed. S. T. E. Abedon (Cambridge, UK: Cambridge University Press), 251-280.

Thomas, T., Gilbert, J., and Meyer, F. (2012). Metagenomics - a guide from sampling to data analysis. Microb. Inform. Exp. 2:3. doi: 10.1186/2042-5783-2-3

Thomas, J. A., Soddell, J. A., and Kurtböke, D. Í. (2002). Fighting foam with phages? Water Sci. Technol. 46, 511-518. doi: 10.2166/wst.2002.0527

Thurber, R. V., Haynes, M., Breitbart, M., Wegley, L., and Rohwer, F. (2009). Laboratory procedures to generate viral metagenomes. Nat. Protoc. 4, 470-483. doi: $10.1038 /$ nprot.2009.10

Tolstoy, I., Koprinski, A. M., and Brister, J. R. (2018). Bacteriophage taxonomy: an evolving discipline. Methods Mol. Biol. 1693, 57-71. doi: 10.1007/978-1-4939-7395-8_6

Wagner, M., and Loy, A. (2002). Bacterial community composition and function in sewage treatment systems. Curr. Opin. Biotechnol. 13, 218-227. doi: 10.1016/S0958-1669(02)00315-4

Walker, J. M., Kropinski, A. M., and Lavigne, R. (2018). Bacteriophages - Methods and Protocols. New York, USA.

Wang, X., Kim, Y., Ma, Q., Hong, S. H., Pokusaeva, K., Sturino, J. M., et al. (2010). Cryptic prophages help bacteria cope with adverse environments. Nat. Commun. 1:147. doi: 10.1038/ncomms1146

Weinbauer, M. G. (2004). Ecology of prokaryotic viruses. FEMS Microbiol. Rev. 28, 127-181. doi: 10.1016/j.femsre.2003.08.001

Weinbauer, M. G., and Rassoulzadegan, F. (2004). Are viruses driving microbial diversification and diversity? Environ. Microbiol. 6, 1-11. doi: $10.1046 / j .1462-2920.2003 .00539 . x$
Weitz, J. S. (2015). Quantitative Viral Ecology: Dynamics of Viruses and Their Microbial Hosts. New York, USA: Princeton University Press.

Wen, K., Ortmann, A. C., and Suttle, C. A. (2004). Accurate Estimation of Viral Abundance by Epifluorescence Microscopy. Appl. Environ. Microbiol. 70, 3862-3867. doi: 10.1128/AEM.70.7.3862-3867.2004

Williamson, K. E., Radosevich, M., and Wommack, K. E. (2005). Abundance and diversity of viruses in six Delaware soils. Appl. Environ. Microbiol. 71, 3119-3125. doi: 10.1128/AEM.71.6.3119-3125.2005

Williamson, K. E., Wommack, K. E., and Radosevich, M. (2003). Sampling Natural Viral Communities from Soil for Culture-Independent Analyses. Appl. Environ. Microbiol. 69, 6628-6633. doi: 10.1128/AEM.69.11.6628-6633.2003

Withey, S., Cartmell, E., Avery, L. M., and Stephenson, T. (2005). Bacteriophages Potential for application in wastewater treatment processes. Sci. Total Environ. 339, 1-18. doi: 10.1016/j.scitotenv.2004.09.021

Wu, Q., and Liu, W. T. (2009). Determination of virus abundance, diversity and distribution in a municipal wastewater treatment plant. Water Res. 43, 1101-1109. doi: 10.1016/j.watres.2008.11.039

Wu, L., Ning, D., Zhang, B., Li, Y., Zhang, P., Shan, X., et al. (2019). Global diversity and biogeography of bacterial communities in wastewater treatment plants. Nat. Microbiol. 4, 1183-1195. doi: 10.1038/s41564-019-0426-5

Wu, B., Wang, R., and Fane, A. G. (2017). The roles of bacteriophages in membrane-based water and wastewater treatment processes: a review. Water Res. 110, 120-132. doi: 10.1016/j.watres.2016.12.004

Xia, Y., Wen, X., Zhang, B., and Yang, Y. (2018). Diversity and assembly patterns of activated sludge microbial communities: a review. Biotechnol. Adv. 36, 1038-1047. doi: 10.1016/j.biotechadv.2018.03.005

Yahya, M., Hmaied, F., Jebri, S., Jofre, J., and Hamdi, M. (2015). Bacteriophages as indicators of human and animal faecal contamination in raw and treated wastewaters from Tunisia. J. Appl. Microbiol. 118, 1217-1225. doi: 10.1111/ jam. 12774

Yang, Q., Zhao, H., and Du, B. (2017). Bacteria and bacteriophage communities in bulking and non-bulking activated sludge in full-scale municipal wastewater treatment systems. Biochem. Eng. J. 119, 101-111. doi: 10.1016/j. bej.2016.12.017

Conflict of Interest: Author Simon Bengtsson was employed by company Promiko AB

The remaining authors declare that the research was conducted in the absence of any commercial or financial relationships that could be construed as a potential conflict of interest.

Publisher's Note: All claims expressed in this article are solely those of the authors and do not necessarily represent those of their affiliated organizations, or those of the publisher, the editors and the reviewers. Any product that may be evaluated in this article, or claim that may be made by its manufacturer, is not guaranteed or endorsed by the publisher.

Copyright (c) 2021 Runa, Wenk, Bengtsson, Jones and Lanham. This is an openaccess article distributed under the terms of the Creative Commons Attribution License (CC BY). The use, distribution or reproduction in other forums is permitted, provided the original author(s) and the copyright owner(s) are credited and that the original publication in this journal is cited, in accordance with accepted academic practice. No use, distribution or reproduction is permitted which does not comply with these terms. 